
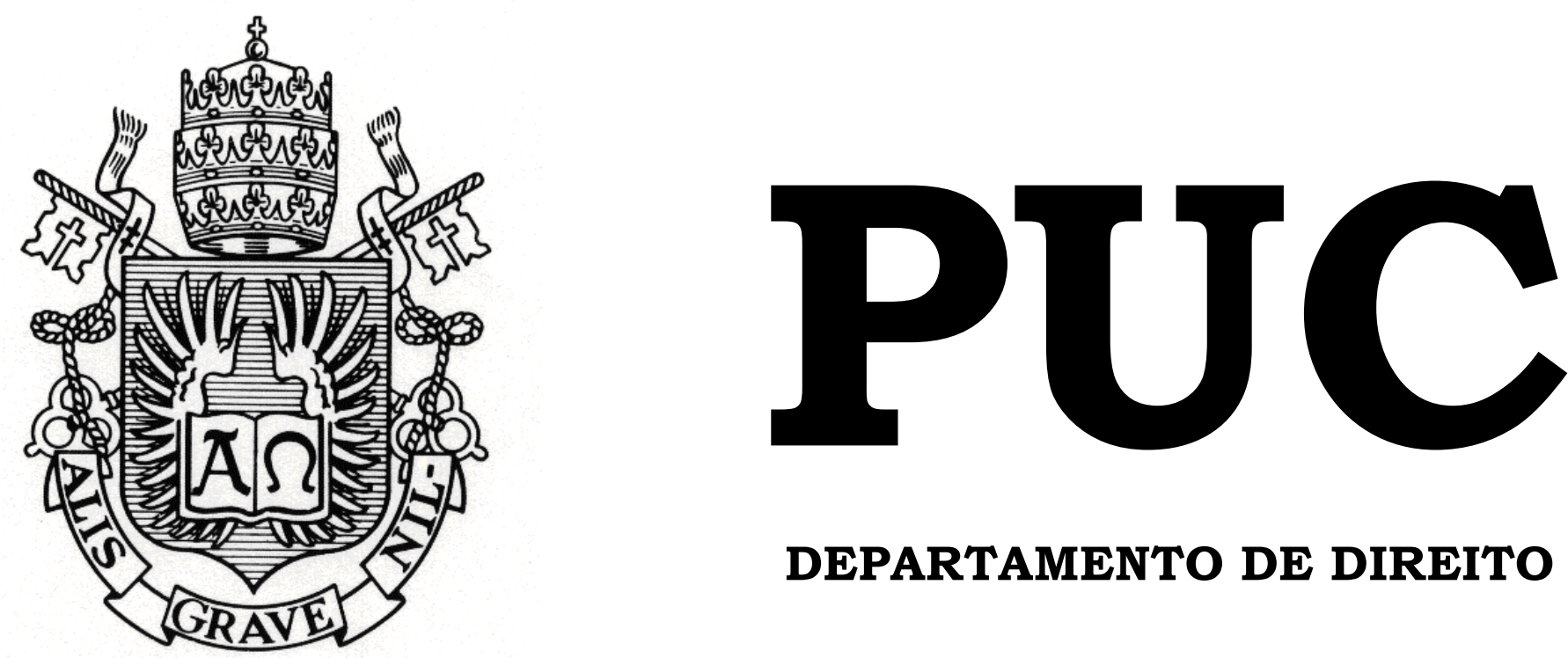

DEPARTAMENTO DE DIREITO

Os principais aspectos da Lei Anticorrupção brasileira 12.846/2013 e a importância da cultura de compliance no ramo empresarial

por

Ingrid Dutra Correia

ORIENTADOR(A): Guilherme Vaz Porto Brechbühler 2015.2

PONTIFÍCIA UNIVERSIDADE CATÓLICA DO RIO DE JANEIRO RUA MARQUÊS DE SÃO VICENTE, 225 - CEP 22453-900 RIO DE JANEIRO - BRASIL 


\title{
Os principais aspectos da lei Anticorrupção brasileira 12.846/2013 e a importância da cultura de compliance no ramo empresarial
}

\author{
por \\ Ingrid Dutra Correia
}

Monografia apresentada ao Departamento de Direito da Pontifícia Universidade Católica do Rio de Janeiro (PUC-Rio) para a obtenção do Título de Bacharel em Direito.

Orientador(a): Guilherme Vaz Porto Brechbühler 
Ao meu pai, Francisco, que não deixou de acreditar em mim por sequer um minuto e foi incansável na minha formação.

A minha mãe, Swellen, que sempre me ensinou a ter valores, esteve presente em todos os momentos e me ensinou a importância da

família. 


\section{AGRADECIMENTOS}

Definitivamente este é um momento muito especial na minha vida. A conquista de um sonho e o início de uma jornada longa para conquistar tantos outros. Devo tudo isso as pessoas maravilhosas que me cercam e por isso deixo aqui registrado o meu mais sincero agradecimento a todos aqueles que contribuíram para minha formação.

Minha eterna gratidão aos meus avós, Walma e Jorge, que sempre foram meus exemplos e possibilitaram as minhas melhores lembranças de uma infância de muito amor e felicidade, que ajudaram a me tornar hoje a pessoa que sou.

A minha família, que sempre me apoiou e comemorou comigo cada vitória.

A minha família do coração alemã, que mesmo de longe sempre se fez presente, participou e me ajudou a ter forças para concluir mais esta etapa.

Aos meus amigos, agradeço por toda a companhia nos momentos felizes e difíceis.

Aos meus amigos da BG do Brasil, que me ensinaram a dar meus primeiros passos como profissional e alegraram meus dias.

As minhas colegas de trabalho e amigas da Saipem do Brasil, por toda a torcida, suporte, amizade e ajuda na hora de escolher o tema deste trabalho.

Ao meu professor, Guilherme, por toda a disponibilidade e suporte nesses longos meses de preparação deste trabalho. 


\section{RESUMO}

O presente trabalho tem por objetivo demonstrar a principal finalidade da Lei 12.846 de $1^{\circ}$ de agosto de 2013 ("Lei Anticorrupção, "Lei" ou Nova Lei"), através da análise dos seus principais temas. Assim, será possível verificar que a lei modifica a maneira de combate à corrupção prevista no ordenamento pátrio, visando principalmente criar mecanismos preventivos a serem implementados pelas pessoas jurídicas que atuam no âmbito nacional.

O primeiro capítulo apresenta o histórico da chegada da corrupção no Brasil a fim de possibilitar a melhor compreensão do cenário atual. No capítulo seguinte, busca-se esclarecer o significado da palavra corrupção, bem como sua previsão legal anterior a Nova Lei e aspectos relevantes do seu projeto de lei (PL6.826/2010). Em seguida, apresentamos o significado de compliance, no que consiste um programa de integridade/compliance e como ele pode amenizar as sanções impostas à pessoa jurídica, no âmbito da Lei Anticorrupção. O capítulo central do presente trabalho, tratará dos principais temas da Nova Lei como por exemplo responsabilidade objetiva da pessoa jurídica, acordos de leniência e sanções. Por fim, através de uma análise do atual contexto internacional e nacional, demonstraremos a importância da Lei Anticorrupção.

\section{PALAVRAS-CHAVE}

ANTICORRUPÇÃO - CORRUPÇÃO - LEI No 12.846 - COMPLIANCE -

DECRETO 8.420 - ACORDO DE LENIÊNCIA - DESCONSIDERAÇÃO 


\section{SUMÁRIO}

Pág.

1. INTRODUÇÃO . .07

2. ASPECTOS HISTÓRICOS DA CORRUPÇÃO NO BRASIL .09

3. O QUE É CORRUPÇÃO.. 13

4. O SIGNIFICADO DE COMPLIANCE

5. A LEI $12.846 \mathrm{DE} 1^{\circ} \mathrm{DE}$ AGOSTO DE 2013. .25

5.1 Considerações Gerais. .25

5.2 Responsabilidade objetiva da pessoa jurídica .26

5.3 Desconsideração compulsória da personalidade jurídica. .31

5.4 Acordo de Leniência. 37

5.5 Sanções .40

5.6 Prescrição. .44

6. A IMPORTÂNCIA DA NOVA LEI NO CONTEXTO ATUAL

6.1 FCPA 


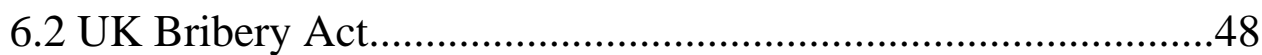

6.3 Li Anticorrupção no cenário nacional.................................49

7. CONCLUSÃO

REFERÊNCIAS BIBLIOGRÁFICAS ...............................................53 


\section{Introdução}

O fenômeno da corrupção em grandes escalas, infelizmente, não é nenhuma novidade para a população brasileira. Em um país tão desigual, a corrupção tem efeitos devastadores: suga cifras inimagináveis de recursos públicos todos os anos, que poderiam e deveriam ser investidos em serviços públicos com o intuito de atender ao bem estar social, deixando a população sem acesso de qualidade aos seus direitos fundamentais resguardados na Constituição Federal de 1988.

Os dados apresentados no relatório da Federação das Indústrias de São Paulo (FIESP), apresentam estimativa de que o custo médio da corrupção no Brasil pode variar no percentual de 1,38\% a 2,3\% do Produto Interno Bruto (PIB), em consequência, o desperdício de recursos públicos que pode chegar a $\mathrm{R} \$ 50,8$ bilhões a $\mathrm{R} \$ 84,5$ bilhões por ano ${ }^{1}$.

A nova Lei Anticorrupção tem por principal objetivo não somente trazer sanções rigorosas para a prática de corrupção por pessoas jurídicas, mas também instituir e incentivar a criação de mecanismos para a prevenção destes atos ilícitos, permitindo cada vez mais a transparência no mundo corporativo, de forma a resguardar a democracia.

Pode-se dizer que a lei visa suprir a lacuna legal que havia em nosso ordenamento quanto a penalidade de pessoas jurídicas que praticam atos contra a Administração Pública, fugindo da sua verdadeira função social prevista na Constituição Federal de 1988 em seu artigo 5º, XXIII ${ }^{2}$, sendo muitas vezes utilizada para mascarar atos ilícitos que prejudicam diretamente o erário e consequentemente ferem o Estado Democrático de Direito, na medida em que reduz investimentos no país e ampliam as desigualdades sociais.

\footnotetext{
1 NETO MOREIRA, Diogo de Figueiredo e FREITAS, Rafael Véras. A juridicidade da Lei Anticorrupção - Reflexões e interpretações prospectivas. Fórum Administrativo-FA. Belo Horizonte, ano 14, n.156, o.9-20, fev. 2014.

${ }^{2}$ Art $5^{\circ}$ - Todos são iguais perante a lei, sem distinção de qualquer natureza, garantindo-se aos brasileiros e aos estrangeiros residentes no País a inviolabilidade do direito à vida, à liberdade, à igualdade, à segurança e à propriedade, nos termos seguintes:(...) XXIII - a propriedade atenderá a sua função social (...)
} 
O formalismo processual de alguns diplomas do ordenamento jurídico pátrio acaba engessando as atividades do poder público. É o caso, por exemplo da Lei 8.666/1993, que embora seu objetivo fosse combater a corrupção e fraude nas licitações públicas, o que aconteceu foi a paralisação de contratações com o poder público que desencadeou na prática de atos de corrupção pelas empresas que participam de licitações, verificando-se nestas situações o pagamento de subornos e formações de cartéis ${ }^{3}$.

Além da necessidade interna, o diploma está em consonância com normas internacionais que visam combater a corrupção. Vale mencionar ainda, que em 2007 a Organização para Cooperação e Desenvolvimento Econômico (OCDE) ao analisar as medidas e mecanismos utilizados pelo Brasil no combate a corrupção, recomendou que fossem implementadas modificações na legislação a fim de possibilitar a responsabilização das empresas que praticassem atos de corrupção contra agentes públicos ${ }^{4}$.

Não obstante, o Congresso Nacional, com a promulgação da Lei 12.846/2013, visou dar uma resposta as manifestações populares de junho de 2013, que protestavam por uma democracia participativa, efetividade política, redução da corrupção no país, dentre outros.

Pode-se afirmar assim, que a Nova Lei tenta suprir a uma lacuna visivelmente presente em nosso ordenamento, cumprir com acordos, normas e tratados internacionais e principalmente exercer função preventiva, criando uma cultura consciente e mecanismos efetivos para a prevenção de atos de imoralidade que tragam prejuízos ao erário, punindo as pessoas jurídicas quando necessário e resguardando o principio constitucional da função social da empresa.

\footnotetext{
${ }^{3}$ MOREIRA NETO, Diogo de Figueiredo e FREITAS, Rafael Véras, Op. Cit., p. 9-20

${ }^{4}$ ORGANIZAÇÃO PARA A COOPERAÇÃO E DESENVOLVIMENTO ECONÔ- MICO - OCDE. Relatório sobre a aplicação da Convenção sobre o Combate ao Suborno de Funcionários Públicos Estrangeiros em Transações Comerciais Internacionais e a Recomendação Revisada de 1997 sobre o Combate ao Suborno em Transações Comerciais Internacionais da OCDE de dezembro de 2007
} 


\section{Aspectos Históricos da Corrupção no Brasil}

Acredita-se que a corrupção tenha chegado ao Brasil junto com a colonização portuguesa. Não é possível saber se antes os índios praticavam atos similares ou mesmos próprios de corrupção com outras tribos, entretanto, é possível verificar que após a chegada dos portugueses em terras brasileiras, os índios precisavam recorrer a meios alternativos para tentarem sobreviver a nova realidade europeia ${ }^{5}$. Assim, a política colonial avassaladora e desigual proporcionava um cenário propício a pequenos atos antiéticos entre os índios, entretanto, estas ações foram pequenas diante da regência portuguesa que à época já era famosa pelos seus desvios de dinheiro ${ }^{6}$.

A vinda da família real portuguesa, bem como das nobres famílias não eram muito bem vistas e muito menos almejadas. Desta forma, a coroa era permissiva e concedia diversas regalias para quem se propusesse a vir morar no Brasil. Foi neste contexto de descaso da coroa que reinava a oceanos de distância, que o Brasil se tornou propício à corrupção, onde o poder e a pessoa que o detinham eram vistos como uma só coisa ${ }^{7}$.

A colonização no Brasil teve desde o início cunho meramente exploratório. Não havia o intuito ideológico em formar aqui, uma nova nação e assim, os que aqui chegavam visavam única e exclusivamente enriquecer de forma exacerbada as custas da recém nascida Colônia, por meio de constantes desvios na arrecadação de tributos e remessa de mercadorias ${ }^{8}$. Desta forma é possível notar nas palavras de Hekelson Bitencourt Viana da Costa:

\footnotetext{
${ }^{5}$ Disponível em: http://www.contracorrupcao.org/2013/08/como-era-corrupcao-na-epoca-do.html Acesso em 19/08/2015

${ }^{6}$ Ibidem

${ }^{7}$ BARBA, Mariana. Corrupção no Brasil tem origem no período colonial. BBC Brasil, São Paulo, 4 nov 2012, disponível em < http://www.bbc.com/portuguese/noticias/2012/11/121026_corrupcao_origens_mdb.shtml> Acesso em 20/08/2015

${ }^{8}$ DA COSTA, Hekelson Bitencourt Viana. Lavagem de Dinheiro - Lei $n^{\circ}$ 9.613/98. Revista de Informação Legislativa. Brasília a. 38 n. 150 abr./jun. 2001. Disponível em $<$ http://www2.senado.leg.br/bdsf/bitstream/handle/id/682/r150-08.pdf?sequence=4> Acesso em $02 / 09 / 2015$
} 
(...) Nosso atraso não é de cunho ético, por influência indígena ou africana, mas, sim, de uma política distorcida da Metrópole, sem um objetivo cultural ou projeto político a ser perseguido pelos habitantes das terras brasileiras, que, oprimidos e entregues à própria sorte, viram na corrupção uma forma fácil de enriquecimento, sem nenhuma implicação ética na relação dominante/dominado. É nessa relação que a corrupção apresenta peculiaridades circunstanciais, mais do que do caráter de um povo, pois não havia uma unicidade de pensamento, daí não se poder identificar a índole do povo brasileiro como má ou distorcida. O comportamento do homem comum estava espelhado na forma de agir da Metrópole. ${ }^{9}$

Vale destacar que apesar da corrupção ter tido forte papel no desenvolvimento da cultura e estruturas de poder no Brasil, esta não é uma prática exclusiva do nosso país, mas sim um problema mundial o qual veremos mais a frente.

Além destes fatores iniciais da colonização, a dominação portuguesa teve cunho tradicional patrimonial cujo cerne não partia de uma estrutura racional de poder, mas sim de uma estrutura volúvel e pessoal, sem qualquer critério, ficando os dominados sujeitos as arbitrariedades do soberano ${ }^{10}$.

Vale ressaltar que a estrutura administrativa tradicional é composta por pessoas diretamente ligadas aquele que detém o poder, construindo assim uma dominação pautada não na competência daqueles que operam a máquina pública, mas sim através de uma pirâmide estratégica, pensada para perpetuar o poder por meio da distribuição de privilégios, favores, regalias e o que se fizer necessário para que a continuidade do exercício do poder seja possível. Cria-se assim a figura do "jeitinho brasileiro". Reinhard Bendix afere que no patrimonialismo a relação entre o governante e a administração é tida como pessoal e discricionária, conforme pode-se verificar:

\footnotetext{
${ }^{9}$ Ibidem

${ }^{10}$ NETO, Affonso Ghizzo. Corrupção, Estado Democrático de Direito e Educação, 2008, p. 20. Disponível o_e_educacao.pdf> Acesso em19/08/2015
} 
No patrimonialismo, o governante trata toda a administração política como seu assunto pessoal, ao mesmo modo como explora a posse do poder político como um predicado útil de sua propriedade privada. Ele confere poderes a seus funcionários, caso a caso, selecionando-os e atribuindo-lhes tarefas específicas com base na confiança pessoal que neles deposita e sem estabelecer nenhuma divisão de trabalho entre eles. [...] Os funcionários, por sua vez tratam o trabalho administrativo, que executam para o governante como um serviço pessoal, baseado em seu dever de obediência e respeito. [...] Em suas relações com a população, eles podem agir de maneira tão arbitrária quanto aquela adotada pelo governante em relação a eles, contanto que não violem a tradição e o interesse do mesmo na manutenção da obediência e da capacidade produtiva de seus súditos. $[\ldots . .]^{11}$

Esta forma de estruturar o poder de forma tradicional e familiar, bem como doméstico e pessoal, levaram a formação de monopólio de cargos públicos, que apesar de terem sido suprimidos pela norma constitucional em seu artigo 37, II da carta de $1988^{12}$, a qual prevê a necessidade do concurso público, ainda deixa evidente em nosso país a fraude e a pessoalidade nos cargos públicos.

O Brasil passou por diversos processos históricos e políticos que amplificaram o conceito corrupção, a forma com que ela se perpetua na sociedade, bem como os mecanismos para combatê-la. Mesmo passando por um processo modernizador a partir do século XX, o qual visava um Estado mais racional e menos emocional, cujos objetivos pautavam-se na formação de ordem pública nos moldes do capitalismo e desenvolvimento político ${ }^{13}$, não se pode negar que a herança histórica deixada pela colonização portuguesa ainda são evidentes na sociedade nos mais diversos ramos comportamentais. A legitimação da corrupção e a imposição do poder, dentro de um sistema que o poder do mais forte impera sobre o mais fraco, são apenas algumas delas. Um ponto relevante dessa modernização almejada pelo Brasil, e que permanece até certo ponto nos dias de hoje, visava o Estado como principal personagem transformador:

\footnotetext{
11 APUD SILVEIRA, Daniel Barile da, op. cit. Disponível em: <http://portalrevistas.ucb.br/index.php/rvmd/article/viewfile/2598/1589.html> Acesso em 19/08/2015

12 " Art. 37. A administração pública direta e indireta de qualquer dos Poderes da União, dos Estados, do Distrito Federal e dos Municípios obedecerá aos princípios de legalidade, impessoalidade, moralidade, publicidade e eficiência e, também, ao seguinte: (...)II - a investidura em cargo ou emprego público depende de aprovação prévia em concurso público de provas ou de provas e títulos, de acordo com a natureza e a complexidade do cargo ou emprego, na forma prevista em lei, ressalvadas as nomeações para cargo em comissão declarado em lei de livre nomeação e exoneração(...)."

${ }^{13}$ FILGUEIRAS, Fernando. A tolerância à corrupção no Brasil: uma antinomia entre normas morais $e$ prática social. OPINIÃO PÚBLICA, Campinas, vol. 15, nº 2, Novembro, 2009, p.391. Disponível em < http://www.scielo.br/pdf/op/v15n2/05.pdf> Acesso em 02/09/2015.
} 
Isso acarretou o fato de vincularmos, historicamente, o problema da corrupção a uma visão estatal, em que a correção das delinquências do homem público brasileiro passaria pela mudança da máquina administrativa, e não dos valores e práticas presentes na sociedade. ${ }^{14}$

Apesar de palpável na cultura brasileira até os dias atuais, a herança portuguesa não é a única culpada pelos altos índices de corrupção no Brasil que, segundo a Transparência Internacional em publicação do reporte anual do Índice de Percepção de Corrupção (IPC) de 2014, o Brasil ocupa o sexagésimo nono lugar no ranking ${ }^{15}$. A precariedade da educação e a ausência de um Estado que proporcione condições dignas ao desenvolvimento e acesso a informação e cultura, bem como um sistema administrativo defasado pela impunidade e direcionado para atribuir vantagens a poucos, contribuem para que a corrupção seja legitimada não só nas esferas públicas de poder, mas também no âmbito privado.

No Estado Democrático de Direito não há mais espaço para que haja qualquer tipo de legitimação de qualquer tipo de corrupção. É necessário transformar a cultura brasileira quanto a este ponto, enfatizando o repúdio aos atos antiéticos, sejam eles irrisórios ou de grande impacto, sejam eles praticados por políticos ou cidadãos, porque no final, seja no âmbito privado ou público, o prejuízo recairá sempre para a sociedade.

\footnotetext{
${ }^{14}$ Ibidem

${ }^{15}$ Disponível em < http://www.transparency.org/cpi2014> Acesso em 02/09/2015
} 


\section{3. $O$ que é corrupção?}

A palavra corrupção tem sua origem do latim "corruptio", que denota decomposição, desmoralização, ação de destruir, depravar ou adulterar ${ }^{16}$. No dicionário Houaiss a palavra corrupção é definida como:

1. Ato, processo ou efeito de corromper; 2. depravação de hábitos, costumes, etc.; devassidão; 3. ato ou efeito de subornar uma ou mais pessoas em causa própria ou alheia, com oferecimento de dinheiro, suborno; 4. emprego, por parte de grupo de pessoas de serviço público e/ou particular, de meios ilegais para, em benefício próprio, apropriar-se de informações privilegiadas, causando crime de lesa pátria $(. . .)^{17}$

Segundo a Transparência Internacional, a corrupção pode ser definida como o "abuso do poder confiado a alguém em benefício privado"18 .No Brasil frequentemente a palavra corrupção é associada tão somente a atos ilegais perpetuados pelo poder público e as elites econômicas, entretanto, igualmente é considerado como corrupção atos de menores proporções e que ocorrem mais frequentemente tanto com servidores públicos quanto com cidadãos comuns que de alguma forma, burlam a lei para auferir vantagem em benefício próprio ou de outrem. Muitos são os sentidos os quais podem ser conferidos a palavra corrupção, conforme mencionamos acima. Contudo, vale ressaltar que em todos os casos há a interação direta de uma ou mais pessoas que corrompem ou se deixam corromper, em troca de algum benefício, ultrapassando os limites legais não só do ordenamento jurídico pátrio, mas muitas vezes também, de regras que permeiam as relações internacionais, como por exemplo convenções internacionais.

No ordenamento jurídico pátrio, até o ano de 2013, as pessoas físicas eram punidas mais severamente pelo ato de corrupção, constituindo crime qualificado nos termos do Código Penal - Decreto Lei 2.848 de 07 de dezembro de 1940, podendo ser classificada como ativa ou passiva. A corrupção ativa ocorre quando

\footnotetext{
16 Bittencourt, Sidney. Comentários à Lei Anticorrupção: Lei 12.846/2013, 2a ed. revista, atualizada e ampliada - São Paulo: Editora Revista dos Tribunais, 2015, p. 21

${ }^{17}$ Houaiss, Antônio. Dicionário Houaiss

${ }^{18}$ POPE, J. The Elements of a National Integrity System. Transparency International source book 2000.
} 
o particular que não exerce qualquer cargo público, oferece vantagem indevida a funcionário público em troca de algum tipo de favor ou benefício, a simples oferta já caracteriza o crime tipificado no artigo 333 do Código Penal, podendo a pena chegar até 12 anos de reclusão e multa ${ }^{19}$. A corrupção passiva constitui ato do funcionário público ao solicitar ou receber vantagem ou qualquer promessa em troca de algum tipo de favor, facilitação ou benefício ao particular, sendo tal conduta devidamente tipificada no artigo 317 do Código Penal. Da mesma forma, ainda que o particular não aceite a proposta, a simples oferta configura o crime de corrupção passiva, ensejando pena de até 12 anos de reclusão e multa ${ }^{20}$.

Art. 317 - Solicitar ou receber, para si ou para outrem, direta ou indiretamente, ainda que fora da função ou antes de assumi-la, mas em razão dela, vantagem indevida, ou aceitar promessa de tal vantagem:

Pena - reclusão, de 2 (dois) a 12 (doze) anos, e multa.

$\S 1^{\circ}$ - A pena é aumentada de um terço, se, em consequência da vantagem ou promessa, o funcionário retarda ou deixa de praticar qualquer ato de ofício ou o pratica infringindo dever funcional.

$\S 2^{\circ}$ - Se o funcionário pratica, deixa de praticar ou retarda ato de ofício, com infração de dever funcional, cedendo a pedido ou influência de outrem:

Pena - detenção, de três meses a um ano, ou multa.

Art. 333 - Oferecer ou prometer vantagem indevida a funcionário público, para determiná-lo a praticar, omitir ou retardar ato de ofício:

Pena - reclusão, de 2 (dois) a 12 (doze) anos, e multa.

Parágrafo único - A pena é aumentada de um terço, se, em razão da vantagem ou promessa, o funcionário retarda ou omite ato de ofício, ou o pratica infringindo dever funcional.

A corrupção está presente nas mais diversas sociedades, em todos os cantos do mundo, não sendo portanto, exclusividade do Brasil. Ocorre que, nos países em desenvolvimento e com menor disponibilidade de mecanismos políticos-legais de controle, o impacto é muito maior, uma vez que propicia a apropriação de recursos públicos que deveriam ser voltados para a garantia dos direitos fundamentais da nossa Constituição Federal. Mostra-se portanto, que a corrupção afeta diretamente o Estado Democrático de Direito, na medida em que

\footnotetext{
${ }^{19}$ Disponível em <http://www.tjdft.jus.br/>

${ }^{20}$ ibidem.
} 
tal prática confronta a dignidade da pessoa humana, pois ao drenar os recursos públicos estão retirando da sociedade seu acesso ao mínimo existencial, necessário para garantia de seus direitos fundamentais. A corrupção é, portanto, a negação da república ${ }^{21}$.

Nesta perspectiva, nota-se que, apesar da tipificação do crime de corrupção no ordenamento jurídico pátrio, na esfera do direito penal, não havia até o ano de 2013 lei que enquadrasse a pessoa jurídica que praticasse este tipo de crime, sendo estas punidas apenas com penalidades administrativas, como por exemplo o impedimento de participação em licitações públicas e celebração de contratos com a Administração Pública ${ }^{22}$ nos termos da lei 8.666 de 1993. Assim o projeto de lei que originou a lei 12.846/2013, tem por objetivo suprir lacuna presente no nosso ordenamento jurídico com relação à responsabilização das pessoas jurídicas pela prática de ilícitos, especialmente quando estes forem contra a Administração Pública ${ }^{23}$.

Este tipo de prática está inserida dentro de um contexto histórico e pode ser tida até mesmo como um produto do sistema econômico ${ }^{24}$. Desta forma, o capitalismo maximiza a sensação de necessidade de sucesso e lucro a todo o custo, criando um cenário propício a prática do crime de corrupção, onde a relação estabelecida entre corruptor e corrompido, busca minimizar os custos e maximizar as oportunidades ${ }^{25}$. A corrupção apresenta-se nesta ótica como um meio para que a satisfação de seus interesses ocorra de forma mais rápida, burlando a burocracia e regras do setor público. Há uma clara mitigação do interesse público em favor do interesse particular, passando o agente público, ao aceitar a vantagem oferecida por particular, a exercer suas funções não apenas

21 Disponível em <http://www.oab.org.br/noticia/27880/oab-se-manifesta-contra-a-corrupcao-e-pelodireito-de-defesa>

22 BITTENCOURT, Sidney. Comentários à Lei Anticorrupção: Lei 12.846/2013, 2a ed. revista, atualizada e ampliada - São Paulo: Editora Revista dos Tribunais, 2015, p. 25

23 Exposição de Motivos do PL 6.826/2010. Disponível em: http://www.camara.gov.br/proposicoesWeb/prop_mostrarintegra;jsessionid=A960D383A530729356645 A9A86AD66AD.node1?codteor=1084183\&filename=Avulso+-PL+6826/2010 Acesso em 01/06/2015

${ }^{24}$ GODINHO, Thiago. Contribuições Do Direito Internacional Ao Combate à Corrupção. In: Rev. Fac. Direito UFMG, Belo Horizonte, n. 58, p. 352, jan./jun. 2011

${ }^{25}$ GARCIA, Emerson. A corrupção. Uma Visão Juridico-Sociológica, 2008, p. 11, disponível em: < http://www.tjrj.jus.br/institucional/dir_gerais/dgcon/pdf/artigos/direi_const/a_corrupcao_uma_visao.pdf> 
em virtude do interesse público e direito da coletividade, mas em prol do interesse privado $^{26}$.

A prática de corrupção no âmbito privado pode causar sérios riscos a sociedade, como desestabilização da economia, crise em setores afetados com a redução de emprego e falta de investimentos no país. Outra consequência é que quando "numa empresa, onde corromper agentes públicos é considerado uma prática "normal", todas as relações, inclusive as internas são afetadas. Se é admitido o pagamento de propinas para se vencer uma licitação, também se admitem gorjetas aos compradores de seus clientes privados. Como decorrência inevitável, enfrenta-se a ameaça permanente de seus próprios compradores serem "comprados" pelos fornecedores. A fraude passa a incorporar a cultura da empresa."27

No dia 3 de dezembro de 2014, foi divulgado pela ONG Transparência Internacional ranking internacional que mede a percepção da corrupção, no qual o Brasil se mostrou em posição longe de ser satisfatória, entretanto, apesar dos mais recentes escândalos envolvendo os crimes de corrupção incessante no país como o mensalão e a corrupção na Petrobras (Operação Lava Jato), o Brasil continua ocupando a mesma posição de quatro anos atrás, ou seja, permanece estagnado na $69^{\mathrm{a}}$ posição ${ }^{28}$.

Diante do exposto, nasce a necessidade de maior rigidez no combate a corrupção não apenas de pessoas físicas, mas também das pessoas jurídicas que cometem este crime, cujo impacto afeta de forma relevante a sociedade como um todo. Não se pode admitir que a pessoa jurídica utilize da sua personalidade jurídica autônoma para encobrir atos contra legem e contra o interesse público, provocando danos as mais diversas camadas da população, puramente por não haver tipificação de tal conduta na lei, bem como suas penalidades. Por isso a nova lei, com relação a responsabilização na esfera administrativa, prevê meios para tentar impedir a prática de constituir novas empresas com o único propósito

\footnotetext{
${ }^{26}$ Ibidem.

${ }^{27}$ GIOVANNI, Wagner. Compliance A excelência na prática, $1^{\mathrm{a}}$ ed. -São Paulo, 2014, p. 23

${ }^{28}$ Rossi, Mariana. Ranking Internacional de corrupção mostra um Brasil estagnado. El País, São Paulo, 3 dez 2005, disponível em < http://brasil.elpais.com>
} 
de burlar sanções administrativas e que tais empresas continuem mantendo relações com a Administração Pública ${ }^{29}$.

O controle da corrupção de forma incisiva é uma tendência mundial e, nos dias de hoje, assume cada vez mais papel fundamental para que seja possibilitado o fortalecimento das instituições democráticas e o crescimento progressivo da economia do país. Assim, após anos em trâmite no Congresso Nacional, em resposta ao atual contexto político -social no qual o Brasil se encontra, incluindo os protestos ocorridos em junho de 2013 e a corrupção generalizada no setor público e privado, bem como a tendência mundial de combate a corrupção, foi promulgada a Lei 12.846 de 01 de agosto de 2013, denominada "Lei Anticorrupção".

A influência imposta pela globalização nas relações internacionais, trazem a crescente necessidade de cooperação mútua entre os Estados para que o desenvolvimento seja atingido ${ }^{30}$. Sendo assim, a lei que teve origem de um projeto submetido pelo Poder Executivo ao Congresso Nacional visa cumprir os compromissos assumidos pelo Brasil ao ratificar convenções contra a corrupção em nível Internacional, sendo elas: a "Convenção sobre o Combate da Corrupção de Funcionários Públicos Estrangeiros em Transações Comerciais Internacionais" da Organização para Cooperação e Desenvolvimento Econômico-OCDE; "Convenção Interamericana contra a Corrupção" da Organização dos Estados Americanos-OEA e; "Convenção das Nações Unidas contra a Corrupção" da Organização das Nações Unidas-ONU. O combate a corrupção ganha destaque na medida em que existe uma necessidade de ações coordenadas entre países, com objetivo de reforçar a ordem moral das instituições democráticas e promoção do desenvolvimento integrado ${ }^{31}$. O Brasil, ao ratificar tais convenções, se comprometeu ao combate efetivo à corrupção, tanto de pessoas jurídicas quanto de pessoas físicas.

\footnotetext{
29 Exposição de Motivos do PL 6.826/2010. Disponível em: http://www.camara.gov.br/proposicoesWeb/prop_mostrarintegra;jsessionid=A960D383A530729356645 A9A86AD66AD.node1?codteor=1084183\&filename=Avulso+-PL+6826/2010 Acesso em 12/06/2015

${ }^{30}$ Controladoria Geral da União. Participação do Brasil em Convenções Internacionais sobre o Combate à Corrupção. Disponível em: <https://bvc.cgu.gov.br/bitstream/123456789/2736/1/participacao_do_Brasil_em.pdf>

${ }^{31}$ Ibidem.
} 
Valendo ressaltar ainda, que a Lei $\mathrm{n}^{\circ} 10.467$ de 2002, acrescentou ao Título XI do Código Penal, o art. 337-B, o qual tipificou, entre outros, o crime de corrupção ativa em transação comercial internacional:

Art. 337-B. Prometer, oferecer ou dar, direta ou indiretamente, vantagem indevida a funcionário público estrangeiro, ou a terceira pessoa, para determiná-lo a praticar, omitir ou retardar ato de ofício relacionado a transação comercial internacional.

O Projeto de Lei tramitou no Congresso Nacional durante três anos, sendo que entre 2010 a 2013 o projeto ficou sob análise da Câmara dos Deputados, tendo sido posteriormente encaminhado ao Senado Federal em junho de 2013. A pressão popular contra a corrupção fez com que o Senado Federal atribuísse regime de urgência ao projeto em trâmite, sendo submetido ao Plenário e aprovado no dia 04 de julho de $2013^{32}$.

\begin{abstract}
A iniciativa da Lei Anticorrupção, conhecida como Lei da Empresa Limpa, deveu-se às manifestações de rua de junho de 2013, realizadas em todas as grandes e médias cidades brasileiras, que apontaram, dentre outras questões cruciais, a corrupção generalizada, nos planos federal, estadual e municipal, abrangendo os diversos níveis da administração. Esse quadro se reflete no descrédito generalizado na opinião pública quanto à gestão governamental. Há uma percepção difusa da sociedade civil de que toda e qualquer autoridade é corrupta ${ }^{33}$.
\end{abstract}

No Brasil, empresas tem muitas vezes relações contratuais de qualquer natureza diretamente com o poder público e se envolvem em esquemas de corrupção. Neste contexto, a Lei anticorrupção fortifica a tendência internacional, anteriormente mencionada, de responsabilizar a empresa corruptora, bem como os funcionários envolvidos nos crimes de corrupção ${ }^{34}$.

A exposição de motivos da Lei apresentada ao Presidente da República no dia 23 de outubro de 2009 deixa de forma clara o objetivo central da lei, bem como o porque da opção de responsabilização administrativa em detrimento da responsabilidade penal, conforme exposto abaixo:

\footnotetext{
${ }^{32}$ BITTENCOURT, Sidney. Comentários à Lei Anticorrupção: Lei 12.846/2013, $2^{\mathrm{a}}$ ed. revista, atualizada e ampliada - São Paulo: Editora Revista dos Tribunais, 2015, p. 26

${ }^{33}$ MODESTO, Carvalhosa. A Nova Lei da Empresa Limpa. Estadão, São Paulo, 30 jan 2014. Disponível em < http://opiniao.estadao.com.br/noticias/geral,a-nova-lei-da-empresa-limpa-imp-,1124715>

${ }^{34}$ Ibidem, p. 26
} 


\begin{abstract}
Nesse cenário, torna-se imperativa a repressão aos atos de corrupção, em suas diversas formatações, praticados pela pessoa jurídica contra a Administração Pública nacional e estrangeira. Observe-se que a Administração Pública aqui tratada é a Administração dos três Poderes da República - Executivo, Legislativo e Judiciário - em todas as esferas de governo - União, Distrito Federal estados e municípios -, de maneira a criar um sistema uniforme em todo o território nacional, fortalecendo a luta contra a corrupção de acordo com a especificidade do federalismo brasileiro.

(...)

Observe-se que o presente projeto optou pela responsabilização administrativa e civil da pessoa jurídica, porque o Direito Penal não oferece mecanismos efetivos ou céleres para punir as sociedades empresárias, muitas vezes as reais interessadas ou beneficiadas pelos atos de corrupção. A responsabilização civil, porque é a que melhor se coaduna com os objetivos sancionatórios aplicáveis às pessoas jurídicas, como por exemplo o ressarcimento dos prejuízos econômicos causados ao erário; e o processo administrativo, porque tem-se revelado mais célere e efetivo na repressão de desvios em contratos administrativos e procedimentos licitatórios, demonstrando melhor capacidade de proporcionar respostas rápidas à sociedade ${ }^{35}$.
\end{abstract}

A lei adota ainda a responsabilidade objetiva da pessoa jurídica, não sendo necessária a comprovação de má-fé ou negligência e da responsabilização individual de pessoas físicas, ou seja, a aplicação da lei não fica condicionada a intenção da companhia ou mesmo de seus dirigentes em praticar atos de corrupção. Uma vez constatado o oferecimento ou pagamento de vantagem indevida a funcionário público, bem como qualquer infração aos dispositivos previstos na legislação, a empresa que for beneficiada direta ou indiretamente será automaticamente penalizada pelo ilícito. Desta forma, evita-se a dificuldade probatória de elementos subjetivos ${ }^{36}$. Sendo assim:

O escopo do legislador é fortalecer o ambiente institucional de repressão à corrupção. Ao suprimir a exigência da constatação do dolo ou da imprudência para imputar as sanções previstas, quer-se incentivar a adoção de políticas de integridade e compliance, que evitem qualquer ligação da empresa com pessoas ou outras entidades que possam the trazer problemas ou danos de imagem. ${ }^{37}$

\footnotetext{
35 Exposição de Motivos do PL 6.826/2010. Disponível em: <http://www.camara.gov.br/proposicoesWeb/prop_mostrarintegra;jsessionid=A960D383A530729356645 A9A86AD66AD.node1? codteor=1084183\&filename=Avulso+-PL+6826/2010>

${ }^{36}$ Ibidem, acesso em 01/06/2015

37 BOTTINI, Pierpaolo. A controversa da responsabilidade objetiva na Lei Anticorrupção. Valor Econômico, 9 dez 2014.
} 
Vale ressaltar que a nova lei preserva e considera os princípios de conservação da empresa e a manutenção das relações trabalhistas no que tange o estabelecimento de sanções administrativas e civis.

Sendo assim, é neste contexto que nasce a Lei Anticorrupção com o objetivo de combater a prática de um dos crimes que mais impactam a realidade socioeconômica. do nosso país. 


\section{O significado de compliance}

Compliance é uma palavra derivada do verbo em inglês "to comply", cujo significado é cumprir, adequar-se, seguir ações e requisitos pré-estabelecidos ${ }^{38}$. Sendo assim, no âmbito corporativo, o termo Compliance está estritamente ligado ao fiel e rigoroso cumprimento, pela empresa, de regras, leis e regulamentos internos ou externos, envolvendo todo o corpo de funcionários para que todas as atividades empresariais estejam dentro dos mais altos níveis de qualidade e ética.

O compliance no âmbito empresarial teve sua origem nos Estados Unidos, em instituições financeiras entre os anos de 1913 e 1929, entretanto o conceito não está adstrito apenas aos Bancos, pelo contrário e principalmente no atual cenário mundial, a prática é aplicada a todos os ramos empresariais com o objetivo de conformidade total dos indivíduos e das pessoas jurídicas de forma coletiva para com a ética e a qualidade, tanto em níveis nacionais quanto internacionais ${ }^{39}$.

$\mathrm{O}$ assunto tem ganhado cada vez mais importância no âmbito nacional, tendo em vista que as empresas que cometerem qualquer ato pela prática de atos contra a administração pública, nacional ou estrangeira e forem enquadradas na lei $\mathrm{n}^{\circ} 12.846 / 2013$, poderão ter suas sanções reduzidas se tiverem programas de compliance efetivos e assim conseguirem comprovar. Assim dispõem os artigos art. 18, V e art. 37, IV do Decreto no 8.420, de 18 de março de 2015 ("Decreto"):

Art. 18. Do resultado da soma dos fatores do art. 17 serão subtraídos os valores correspondentes aos seguintes percentuais do faturamento bruto da pessoa jurídica do último exercício anterior ao da instauração do PAR, excluídos os tributos:

(...)

V - um por cento a quatro por cento para comprovação de a pessoa jurídica possuir e aplicar um programa de integridade, conforme os parâmetros estabelecidos no Capítulo IV.

\footnotetext{
${ }^{38}$ GIOVANNI, Wagner. Compliance A excelência na prática, $1^{\text {a }}$ ed. -São Paulo, 2014, p. 20

${ }^{39}$ DOS SANTOS, Renato Almeida; GUEVARA, Arnaldo José de Hoyos; AMORIM, Cristina Sanches e FERRAZ-NETO, Ben-Hur. Compliance e liderança: a suscetibilidade dos líderes ao risco de corrupção nas organizações. Einstein (São Paulo) vol.10 no.1 São Paulo jan./mar. 2012
} 
Art. 37. O acordo de leniência conterá, entre outras disposições, cláusulas que versem sobre:

(...)

IV - a adoção, aplicação ou aperfeiçoamento de programa de integridade, conforme os parâmetros estabelecidos no Capítulo IV.

Desta forma, é de suma importância ter mecanismos de controle efetivos e claros para que caso a empresa seja perquirida nos termos da nova lei anticorrupção, poderá ter sua sanção reduzida. Nestes moldes a Controladoria Geral da União publicou no dia 7 de abril de 2015 a Portaria no 909, cujo objetivo é estabelecer requisitos objetivos para a avaliação dos programas de integridade das pessoas jurídicas, de forma a complementar o disposto na lei $12.846 / 2013$.

Um ponto importante trazido pela Portaria $n^{\circ}$ 909/2015 é que caso o programa de conformidade tenha sido elaborado e entrado em vigor na empresa após o ato lesivo investigado, não será este um ponto positivo, mas sim negativo. O programa de integridade da pessoa jurídica deve ter por objetivo a prevenção e a correção de atos de corrupção contra a Administração Pública. Na mesma linha, o programa deverá ser efetivo e conhecido dentro da empresa, ou seja, é necessário o engajamento e conhecimento de todos, de forma a desenvolver uma cultura de compliance permanente, conduzindo todas as atividades de forma ética, envolvendo não só os diretores mas todos os níveis hierárquico, sendo compliance parte da responsabilidade corporativa. Logo, não serão aceitos para fins de redução de sanções programas meramente de "fachada" ou formais.

A Portaria $n^{\circ}$ 909/2015 especifica por meio de critérios objetivos de que forma e quais requisitos serão necessários para que o programa de conformidade da pessoa jurídica seja avaliado para fins da lei anticorrupção. A empresa deve apresentar um verdadeiro "raio-X" de toda a sua estrutura, funcionamento, gestão e hierarquia divididos em dois documentos, conforme segue: 
Art. $2^{\circ}$ Para que seu programa de integridade seja avaliado, a pessoa jurídica deverá apresentar: I - relatório de perfil; e II - relatório de conformidade do programa ${ }^{40}$.

O relatório de perfil deverá abordar a empresa no aspecto societário organizacional informando por exemplo os setores do mercado os quais atua no mercado nacional e no exterior quando este for o caso, informar o número de empregados, destacar a relevância da obtenção de autorizações, licenças e permissões governamentais para suas atividades, bem como esmiuçar de forma contextualizada as interações estabelecidas com a administração pública nacional ou estrangeira, dentre outros requisitos ${ }^{41}$.

Art. $3^{\circ}$ No relatório de perfil, a pessoa jurídica deverá:

I - indicar os setores do mercado em que atua em território nacional e, se for o caso, no exterior;

II - apresentar sua estrutura organizacional, descrevendo a hierarquia interna, o processo decisório e as principais competências de conselhos, diretorias, departamentos ou setores;

III - informar o quantitativo de empregados, funcionários e colaboradores;

IV - especificar e contextualizar as interações estabelecidas com a administração pública nacional ou estrangeira, destacando:

a) importância da obtenção de autorizações, licenças e permissões governamentais em suas atividades;

b) o quantitativo e os valores de contratos celebrados ou vigentes com entidades e órgãos públicos nos últimos três anos e a participação destes no faturamento anual da pessoa jurídica;

c) frequência e a relevância da utilização de agentes intermediários, como procuradores, despachantes, consultores ou representantes comerciais, nas interações com o setor público;

$\mathrm{V}$ - descrever as participações societárias que envolvam a pessoa jurídica na condição de controladora, controlada, coligada ou consorciada; e

VI - informar sua qualificação, se for o caso, como microempresa ou empresa de pequeno porte ${ }^{42}$.

Por outro lado, o relatório de conformidade do programa deverá indicar de que forma e qual a estrutura deste, devendo estar de acordo com a lei $\mathrm{n}^{\circ}$ $12846 / 2013$ e o decreto $n^{\circ} 8420$ de 2015.

Art. $4^{\circ}$ No relatório de conformidade do programa, a pessoa jurídica deverá: I - informar a estrutura do programa de integridade, com:

\footnotetext{
40 Portaria CGU no909 de 07 de abril de 2015; disponível em: <http://www.cgu.gov.br/sobre/legislacao/arquivos/portarias/portaria_cgu_909_2015.pdf> Acesso em $16 / 09 / 2015$

${ }^{41}$ Ibidem

${ }^{42}$ Ibidem
} 
a) indicação de quais parâmetros previstos nos incisos do caput do art. 42 do Decreto $\mathrm{n}^{\circ}$ 8.420, de 2015, foram implementados;

b) descrição de como os parâmetros previstos na alínea "a" deste inciso foram implementados;

c) explicação da importância da implementação de cada um dos parâmetros previstos na alínea "a" deste inciso, frente às especificidades da pessoa jurídica, para a mitigação de risco de ocorrência de atos lesivos constantes do art. $5^{\circ}$ da Lei $n^{\circ} 12.846$, de $1^{\circ}$ de agosto de 2013;

II - demonstrar o funcionamento do programa de integridade na rotina da pessoa jurídica, com histórico de dados, estatísticas e casos concretos; e

III - demonstrar a atuação do programa de integridade na prevenção, detecção e remediação do ato lesivo objeto da apuração.

$\S 1^{\circ}$ A pessoa jurídica deverá comprovar suas alegações, devendo zelar pela completude, clareza e organização das informações prestadas.

$\S 2^{\circ}$ A comprovação pode abranger documentos oficiais, correios eletrônicos, cartas, declarações, correspondências, memorandos, atas de reunião, relatórios, manuais, imagens capturadas da tela de computador, gravações audiovisuais e sonoras, fotografias, ordens de compra, notas fiscais, registros contábeis ou outros documentos, preferencialmente em meio digital. ${ }^{43}$

O percentual de redução de que trata o art. $8^{\circ}, \mathrm{V}$ do Decreto $n^{\circ}$ 8420/2015, avaliará as informações prestadas no relatório de perfil e no relatório de conformidade do programa de compliance, bem como a comprovação das mesmas, sua efetividade diante do perfil da empresa e seu grau de efetividade, podendo ainda a autoridade responsável solicitar outros documentos e realizar entrevistas que se façam necessárias para a devida avaliação da pessoa jurídica.

\footnotetext{
${ }^{43}$ Ibidem
} 


\section{A Lei 12.846 de $1^{\circ}$ de agosto de 2013}

\subsection{Considerações gerais}

O principal objetivo da lei é propiciar mecanismos efetivos para que sejam implantadas medidas preventivas por partes das empresas (compliance), passando as mesmas a agir com maior transparência, de modo a evitar condutas corruptas, e caso ainda sim tais práticas venham a acontecer, estabelecer meios legislativos próprios para que a responsabilização objetiva e imediata da pessoa jurídica seja possível.

Outro ponto importante da lei reside no fato de instituir sanções econômicas para as pessoas jurídicas, como consequência objetiva pelo descumprimento dos dispositivos legais, servindo de incentivo para que mecanismos institucionais sejam implantados de forma que tais práticas contra legem não ocorram ${ }^{44}$. Apesar da sanção moral não estar afastada do diploma legal, as sanções impostas no artigo $9^{\circ}$ da Lei Anticorrupção ferem diretamente a saúde econômica da empresa que praticar delitos de corrupção.

A pessoa jurídica é formada quase sempre por razão econômica, visa o lucro através do desenvolvimento das atividades empresariais que gozam dos princípios constitucionais do artigo 170 da Constituição Federal ${ }^{45}$, quais sejam a livre iniciativa, livre concorrência e valorização do trabalho humano, desde que permaneçam dentro dos limites legais.

\footnotetext{
${ }^{44}$ MOREIRA, Egon e BAGATIN, Andreia. Lei Anticorrupção e quatro de seus principais temas Responsabilidade objetiva, desconsideração societária, acordos de leniência e regulamentos administrativos. R. de Dir. Público da Economia-RDPE. Belo Horizonte, ano 12, n. 47, p.64, jul./set. 2014

${ }^{45}$ Art. 170. A ordem econômica, fundada na valorização do trabalho humano e na livre iniciativa, tem por fim assegurar a todos existência digna, conforme os ditames da justiça social, observados os seguintes princípios: I - soberania nacional; II - propriedade privada; III - função social da propriedade; IV - livre concorrência; V - defesa do consumidor; VI - defesa do meio ambiente; VI - defesa do meio ambiente, inclusive mediante tratamento diferenciado conforme o impacto ambiental dos produtos e serviços e de seus processos de elaboração e prestação; VII - redução das desigualdades regionais e sociais; VIII busca do pleno emprego; IX - tratamento favorecido para as empresas brasileiras de capital nacional de pequeno porte; IX - tratamento favorecido para as empresas de pequeno porte constituídas sob as leis brasileiras e que tenham sua sede e administração no País; Parágrafo único. É assegurado a todos o livre exercício de qualquer atividade econômica, independentemente de autorização de órgãos públicos, salvo nos casos previstos em lei.
} 
No que tange a constitucionalidade da Nova Lei, nossa Constituição de 1988 assegura através de diversos dispositivos a moralidade administrativa ${ }^{46}$, como por exemplo o disposto no já mencionado art. 37 , caput $^{47}$, o artigo $5^{\circ}$ $\mathrm{LXXIII}^{48}$ que confere a qualquer cidadão o direito de supervisionar os atos do poder público, sendo parte legítima para propor ação popular, dentre outros dispositivos. Assim, espera-se que a Administração Pública desempenhe suas funções pautada na melhor ética. Neste sentido, Moreira Neto e Freitas sustentam a compatibilidade e fundamentação da Lei Anticorrupção na Constituição Federal:

Deflui daí a constitucionalidade de um diploma normativo que tem por objeto justamente a repressão de condutas de agentes privados que fomentem a prática de imoralidades por servidores do Estado, estabelecendo sanções e instrumentos administrativos para a sua persecução ${ }^{49}$.

Os mecanismos para combater atos de corrupção e consequentemente da moralidade administrativa, não devem fixar-se somente aos agente públicos mas também aos agentes privados.

Sendo assim, a seguir serão feitas considerações sobre as inovações mais relevantes da Lei.

\subsection{Responsabilidade objetiva da pessoa jurídica}

A Lei Anticorrupção atribui à pessoa jurídica conceito abrangente em seu artigo $1^{\circ}$, conforme pode-se obervar:

\footnotetext{
${ }^{46}$ MOREIRA NETO, Diogo de Figueiredo e FREITAS, Rafael Véras. A juridicidade da Lei Anticorrupção - Reflexões e interpretações prospectivas. Belo Horizonte. Fórum Administrativo - FA, ano 14 , n. 156 , p. 11 , fev. 2014

${ }^{47}$ Art. 37. A administração pública direta e indireta de qualquer dos Poderes da União, dos Estados, do Distrito Federal e dos Municípios obedecerá aos princípios de legalidade, impessoalidade, moralidade, publicidade e eficiência.

48 Art. $5^{\circ}(\ldots)$ LXXIII - qualquer cidadão é parte legítima para propor ação popular que vise a anular ato lesivo ao patrimônio público ou de entidade de que o Estado participe, à moralidade administrativa, ao meio ambiente e ao patrimônio histórico e cultural, ficando o autor, salvo comprovada má-fé, isento de custas judiciais e do ônus da sucumbência".

${ }^{49}$ MOREIRA NETO, Diogo de Figueiredo e FREITAS, Rafael Véras. Op. Cit., p. 12.
} 
Art. $1^{\mathbf{o}}$ Esta Lei dispõe sobre a responsabilização objetiva administrativa e civil de pessoas jurídicas pela prática de atos contra a administração pública, nacional ou estrangeira.

Parágrafo único. Aplica-se o disposto nesta Lei às sociedades empresárias e às sociedades simples, personificadas ou não, independentemente da forma de organizacão ou modelo societário adotado, bem como a quaisquer fundacões, associacões de entidades ou pessoas, ou sociedades estrangeiras, que tenham sede, filial ou representacão no território brasileiro, constituídas de fato ou de direito, ainda que temporariamente. (grifo nosso)

No âmbito da nova lei, não é relevante a título de responsabilização se a empresa que pratica atos ilícitos tipificados no artigo $5^{\circ}$ da mesma lei, é constituída formalmente ou não ${ }^{50}$. Isto ocorre devido a opção do legislador pela adoção da responsabilidade objetiva da pessoa jurídica por atos praticados contra a administração pública.

A responsabilidade objetiva é aquela que ocorre independente da presença de dolo ou culpa nos termos do artigo 927 parágrafo único do Código Civil Brasileiro de $2002^{51}$.

Logo, tem-se por objetivo quebrar as barreiras impostas para a responsabilização da pessoa jurídica existentes em outros diplomas normativos vigentes, como por exemplo a Lei $n^{\circ}$ 8.666/1993, que muitas vezes não é aplicável a pessoas jurídicas e nem promove o devido ressarcimento dos danos causados $^{52}$. Outro exemplo é a Lei $n^{\circ} 8.429 / 1992$ que versa sobre as sanções aplicáveis aos agentes públicos nos casos de enriquecimento ilícito no exercício de mandato, cargo, emprego ou função na administração pública direta, indireta ou fundacional, mas que exige mesmo nos casos de pessoas jurídicas a prova de culpa grave ou dolo na improbidade, conforme afere jurisprudência do STJ:

\footnotetext{
${ }^{50}$ CUÉLLAR, Leila e PINHO, Clóvis. Reflexões sobre a lei 12.846/2013 (Lei Anticorrupção). Revista de Direito Público da Economia -RDPE. Belo Horizonte, ano 12. n. 46, p. 144, abr./jun.2014

${ }^{51}$ Art. 927(...) parágrafo único. Haverá obrigação de reparar o dano, independentemente de culpa, nos casos especificados em lei, ou quando a atividade normalmente desenvolvida pelo autor do dano implicar, por sua natureza, risco para os direitos de outrem.

52 MOREIRA, Egon e BAGATIN, Andreia. Lei Anticorrupção e quatro de seus principais temas Responsabilidade objetiva, desconsideração societária, acordos de leniência e regulamentos administrativos. R. de Dir. Público da Economia-RDPE. Belo Horizonte, ano 12, n. 47, p.60, jul./set. 2014
} 
ADMINISTRATIVO E PROCESSUAL CIVIL. AÇÃO CIVIL PÚBLICA DE IMPROBIDADE ADMINISTRATIVA CONTRA MAJOR DO CORPO DE BOMBEIROS DO ESTADO DO PARANÁ. REALIZAÇÃO DE OBRAS NA PISCINA DA INSTITUIÇÃO. FRACIONAMENTO DO SERVIÇO JUSTIFICADO PELA IMPREVISIBILIDADE DA DIMENSÃO DA OBRA A SER REALIZADA, QUE SÓ RESTOU VERIFICADA QUANDO INICIADA A REFORMA DA PARTE EXTERNA DA PISCINA. AUSÊNCIA DE DOLO. RECURSO DESPROVIDO. 1. $\underline{A}$ improbidade é uma ilegalidade qualificada pelo intuito malsão do agente, atuando sob impulsos eivados de desonestidade, malícia, dolo ou culpa grave. 2. Dessa atuação malsã do agente, ademais, deve resultar (i) o enriquecimento ilícito próprio ou alheio (art. 9o. da Lei 8.429/92), (ii) a ocorrência de prejuízo ao Erário (art. 10 da Lei 8.429/92) ou (iii) a infringência aos princípios nucleares da Administração Pública (arts. 37 da Constituição e 11 da Lei 8.429/92). 3. Observe-se, ainda, que a conduta do Agente, nos casos dos arts. 90. e 11 da Lei 8.429/92, há de ser sempre dolosa, por mais complexa que seja a demonstracão desse elemento subjetivo; nas hipóteses do art. 10 da Lei 8.429/92, admite-se que possa ser culposa, mas em nenhuma das hipóteses legais se diz que possa a conduta do agente ser considerada apenas do ponto de vista objetivo, gerando a responsabilidade objetiva. (...) (grifo nosso $)^{53}$

$\mathrm{O}$ artigo $2^{\circ}$ da Lei Anticorrupção deixa de forma expressa a opção do legislador pela responsabilidade objetiva da pessoa jurídica:

Art. 20 As pessoas jurídicas serão responsabilizadas objetivamente, nos âmbitos administrativo e civil, pelos atos lesivos previstos nesta Lei praticados em seu interesse ou benefício, exclusivo ou não. (grifo nosso).

Para fins de responsabilização, bastará que seja provado a ocorrência de ato de corrupção, bem como o nexo de causalidade entre o ilícito e a conduta de qualquer um dos representantes da pessoa jurídica, para que a mesma possa ser responsabilizada nos termos da Nova Lei. Não dependendo sequer da prova de condutas comissivas, sendo possível ainda a responsabilização pela simples omissão $^{54}$.

O legislador optou pela responsabilização penal-administrativa das pessoas jurídicas no âmbito da Nova Lei, tendo em vista a dificuldade de condenação da pessoa jurídica no processo penal, considerando que a ausência do dolo caracteriza a falta de um dos elementos do tipo e por consequência o fato

\footnotetext{
${ }^{53}$ REsp n ${ }^{\circ}$ 1216633, Rel. Ministro Napoleão Nunes Maia Filho, T1 - PRIMEIRA TURMA, 22 out. 2013.

54 MOREIRA, Egon e BAGATIN, Andreia. Lei Anticorrupção e quatro de seus principais temas Responsabilidade objetiva, desconsideração societária, acordos de leniência e regulamentos administrativos. R. de Dir. Público da Economia-RDPE. Belo Horizonte, ano 12, n. 47, p.61, jul./set. 2014
} 
ou conduta torna-se atípico sem a prova de dolo ou culpa ${ }^{55}$, não havendo sequer crime.

(...) nem sempre o lesado consegue provar a culpa do agente, seja por desigualdade econômica, seja por cautela excessiva do juiz ao aferi-la, e como resultado, muitas vezes, a vítima não é indenizada, apesar de haver sido lesada. $\mathrm{O}$ direito passou então a desenvolver teorias que preveem o ressarcimento do dano, em alguns casos, sem a necessidade de provar-se a culpa do agente que o causou. Esta forma de responsabilidade civil, de que é exemplo o art. 21, XXIII, d, da Constituição Federal do Brasil, é chamada de teoria objetiva da responsabilidade civil ou responsabilidade sem culpa. ${ }^{56}$

No âmbito civil, almeja-se o ressarcimento do dano decorrente da punição do processo penal-administrativo, cujo processamento ocorrerá mediante ação civil pública.

Em se tratando da pessoa jurídica, não seria possível considerar a presença de dolo ou culpa, uma vez ausente o fator psicológico próprio da pessoa física ${ }^{57}$. A pessoa jurídica deve ater-se fielmente ao cumprimento do seu objeto social, previamente estabelecido no estatuto ou contrato social, para que assim possa cumprir sua finalidade e sua função social.

Ocorre assim, a importação para o direto penal-administrativo da teoria da imputação objetiva, que consiste na análise da conduta-benefício almejado pela pessoa jurídica que pratica o ilícito e não mais na causalidade tipo-dolo ${ }^{58}$.

Não há o que se falar portanto de tipo subjetivo do delito cometido por pessoa jurídica, não existindo dolo uma vez que a mesma é uma ficção jurídica. Há de se ressaltar ainda que da mesma forma, não é aplicável a teoria do risco, própria do Direito Civil para aplicação da culpa objetiva, uma vez que não podemos afirmar conforme afere Modesto Carvalhosa, "que a pessoa jurídica assumiu um risco ao se conduzir de forma corrupta". 59

\footnotetext{
${ }^{55}$ CARVAlHOSA, Modesto. Considerações sobre a Lei Anticorrupção das Pessoas Jurídicas: Lei 12.846/13. $1^{\mathrm{a}}$ ed. São Paulo: Revista dos Tribunais, 2015.p. 39.

56 QUINTO, Cristina Alcântara. 10 Anos do Código Civil de 2002. Disponível em $<$ http://www.emerj.tjrj.jus.br/serieaperfeicoamentodemagistrados/paginas/series/13/volumeI/10anosdocod igocivil_97.pdf> Acesso em 14/10/2015

${ }^{57}$ CARVALHOSA, Modesto. Op. cit., p. 39

${ }^{58}$ CARVALHOSA, Modesto. Op. cit., p. 37.

${ }^{59}$ CARVALHOSA, Modesto. Op. cit., p. 44.
} 
Para fins da Lei Anticorrupção, são considerados atos de corrupção aqueles devidamente tipificados no artigo $5^{\circ}$, conforme segue:

Art. $5^{\circ}$ Constituem atos lesivos à administração pública, nacional ou estrangeira, para os fins desta Lei, todos aqueles praticados pelas pessoas jurídicas mencionadas no parágrafo único do art. 1o, que atentem contra o patrimônio público nacional ou estrangeiro, contra princípios da administração pública ou contra os compromissos internacionais assumidos pelo Brasil, assim definidos:

I - prometer, oferecer ou dar, direta ou indiretamente, vantagem indevida a agente público, ou a terceira pessoa a ele relacionada;

II - comprovadamente, financiar, custear, patrocinar ou de qualquer modo subvencionar a prática dos atos ilícitos previstos nesta Lei;

III - comprovadamente, utilizar-se de interposta pessoa física ou jurídica para ocultar ou dissimular seus reais interesses ou a identidade dos beneficiários dos atos praticados;

IV - no tocante a licitações e contratos:

a) frustrar ou fraudar, mediante ajuste, combinação ou qualquer outro expediente, o caráter competitivo de procedimento licitatório público;

b) impedir, perturbar ou fraudar a realização de qualquer ato de procedimento licitatório público;

c) afastar ou procurar afastar licitante, por meio de fraude ou oferecimento de vantagem de qualquer tipo;

d) fraudar licitação pública ou contrato dela decorrente;

e) criar, de modo fraudulento ou irregular, pessoa jurídica para participar de licitação pública ou celebrar contrato administrativo;

f) obter vantagem ou benefício indevido, de modo fraudulento, de modificações ou prorrogações de contratos celebrados com a administração pública, sem autorização em lei, no ato convocatório da licitação pública ou nos respectivos instrumentos contratuais; ou

g) manipular ou fraudar o equilíbrio econômico-financeiro dos contratos celebrados com a administração pública;

V - dificultar atividade de investigação ou fiscalização de órgãos, entidades ou agentes públicos, ou intervir em sua atuação, inclusive no âmbito das agências reguladoras e dos órgãos de fiscalização do sistema financeiro nacional(...).

O sujeito passivo dos atos tipificados no artigo $5^{\circ}$ previamente transcrito será sempre o Estado, ao passo que somente a pessoa jurídica configurará no polo ativo do ato de corrupção, conforme estabelece o artigo $1^{\circ}$ da mesma Lei.

Não obstante a responsabilização da pessoa jurídica de forma objetiva por atos de corrupção, seus dirigentes e administradores poderão ser penalizados na medida em que forem comprovados a existência de dolo ou culpa grave, nos termos do artigo $3^{\circ}$ da Lei 12.846/13. Todavia, há de se ressaltar que a responsabilização das pessoas físicas será processada na esfera penal e civil e não no âmbito penal-administrativo que trata a Lei Anticorrupção. Visto isso, não poderá a pessoa jurídica alegar em sua defesa o desconhecimento dos delitos de corrupção de seus dirigentes e funcionários, uma vez que o benefício da conduta 
ilícita se reverte em prol da empresa, de forma que não há no que se falar que isenção da responsabilidade uma vez verificado o nexo causal e a conduta delituosa.

Reside por trás da aplicação objetiva, o incentivo as boas práticas corporativas que possibilitem a transparência das atividades empresárias, bem como a minimização da probabilidade de atos de corrupção, posto que não poderá alegar ausência de culpa in vigilando ou mesmo desconhecimento do fato como demonstrado neste capítulo.

\subsection{Desconsideração compulsória da pessoa jurídica}

Um dos pontos mais consideráveis da presente lei no âmbito das sanções possivelmente aplicáveis é a desconsideração compulsória da pessoa jurídica, cuja aplicação gera sua extinção. No presente capítulo analisaremos este instituto trazido pela Lei Anticorrupção.

Vale ressaltar que a desconsideração da personalidade jurídica no âmbito da presente Lei aparece de forma expressa em dois dispositivos: o artigo 19 inciso III e $\S 1^{\circ}$ e incisos I e II, bem como no artigo 14 . O presente capítulo versará sobre o que dispõe no artigo 19, o qual possibilita a desconsideração compulsória, entretanto, insta salientar, ainda que de forma breve, a desconsideração da personalidade jurídica expressa no artigo 14:

Art. 14. A personalidade jurídica poderá ser desconsiderada sempre que utilizada com abuso do direito para facilitar, encobrir ou dissimular a prática dos atos ilícitos previstos nesta Lei ou para provocar confusão patrimonial, sendo estendidos todos os efeitos das sanções aplicadas à pessoa jurídica aos seus administradores e sócios com poderes de administração, observados o contraditório e a ampla defesa.

Este dispositivo não almeja a extinção da pessoa jurídica, mas tão somente sua desconsideração parcial e temporária, de forma a possibilitar atingir o patrimônio e a pessoa física dos sócios quando verificado e comprovado abuso de direito para facilitar, encobrir ou dissimular os atos tipificados no artigo $5^{\circ}$ da Lei Anticorrupção ou ainda de forma a causar confusão patrimonial. 
Nota-se que a confusão patrimonial resta configurada quando "se verifica uma promiscuidade de bens e relações jurídicas entre sócios e/ou administradores e a sociedade ou, mesmo, entre sociedades" (Mamede, 2015, p.236).

O Supremo Tribunal Federal encarou a matéria após a edição da Nova Lei em julgamento do MS 32494 DF. In verbis:

PROCEDIMENTO ADMINISTRATIVO E DESCONSIDERACÃO EXPANSIVA DA PERSONALIDADE JURÍDICA. "DISREGARD DOCTRINE" E RESERVA DE JURISDIÇÃO: EXAME DA POSSIBILIDADE DE A ADMINISTRAĊ̃̃O PÚBLICA, MEDIANTE ATO PRÓPRIO, AGINDO "PRO DOMO SUA", DESCONSIDERAR A PERSONALIDADE CIVIL DA EMPRESA, EM ORDEM A COIBIR SITUACÕES CONFIGURADORAS DE ABUSO DE DIREITO OU DE ORAUDE. A COMPETÊNCIA INSTITUCIONAL DO TRIBUNAL DE CONTAS DA UNIÃO E A DOUTRINA DOS PODERES IMPLÍCITOS. INDISPENSABILIDADE, OU NÃO, DE LEI QUE VIABILIZE A INCIDÊNCIA DA TÉCNICA DA DESCONSIDERAÇÃO DA PERSONALIDADE JURÍDICA EM SEDE ADMINISTRATIVA. A ADMINISTRAÇÃO PÚBLICA E O PRINCÍPIO DA LEGALIDADE: SUPERAÇÃO DE PARADIGMA TEÓRICO FUNDADO NA DOUTRINA TRADICIONAL? O PRINCÍPIO DA MORALIDADE ADMINISTRATIVA:VALOR CONSTITUCIONAL REVESTIDO DE CARÁTER ÉTICO-JURÍDICO, CONDICIONANTE DA LEGITIMIDADE E DA VALIDADE DOS ATOS ESTATAIS. O ADVENTO DA LEI No 12.846/2013 (ART. 5, IV, “e”, E ART. 14), AINDA EM PERÍODO DE "VACATIO LEGIS". DESCONSIDERAÇÃO DA PERSONALIDADE JURÍDICA E O POSTULADO DA INTRANSCENDÊNCIA DAS SANÇÕES ADMINISTRATIVAS E DAS MEDIDAS RESTRITIVAS DE DIREITOS. MAGISTÉRIO DA DOUTRINA. JURISPRUDÊNCIA. PLAUSIBILIDADE JURÍDICA DA PRETENSÃO CAUTELAR E CONFIGURAÇÃO DO "PERICULUM IN MORA".MEDIDA LIMINAR DEFERIDA. Trata-se de mandado de segurança, com pedido de medida liminar, impetrado com o objetivo de questionar a validade jurídica de deliberação que, emanada do E. Tribunal de Contas da União (Processo TC-000.723/2013-4), acha-se consubstanciada em acórdão assim ementado: "REPRESENTAÇÃO. LICITAÇÃO, NA MODALIDADE PREGÃO, PROMOVIDA PELA VALEC S/A, PARA AQUISIÇÃO DE TRILHOS. IRREGULARIDADES GRAVÍSSIMAS. NULIDADES. CONCESSÃO DE MEDIDA CAUTELAR PARA PARALISAÇÃO DOS PROCEDIMENTOS. OITIVA DE TODOS OS PARTICIPANTES DO PROCESSO. REVOGAÇÃO DO PREGÃO PELA VALEC, POSTERIORMENTE À DEMONSTRAÇÃO PELO TCU DAS NULIDADES. PROCEDIMENTO LICITATÓRIO COM UMA ÚNICA POSSIBILIDADE DE FORNECEDOR, DADA A MAGNITUDE DO OBJETO. INEQUÍVOCO DIRECIONAMENTO DA LICITAÇÃO. PRÁTICA DE ATOS COM ABUSO DA PERSONALIDADE JURÍDICA. SIMULAÇÃO. APLICAÇÃO DA TEORIA DA DESCONSIDERAÇÃO DA PERSONALIDADE JURÍDICA. EXTENSÃO DA SANÇÃO APLICADA, COM FUNDAMENTO NO ART. $7^{\circ}$ DA LEI DO PREGÃO, PARA EMPRESA VINCULADA. CONHECIMENTO. PROCEDÊNCIA PARCIAL DA REPRESENTAÇÃO POR MÚLTIPLOS FUNDAMENTOS. DETERMINAÇÕES. CIÊNCIA. (...) - 6) Desconsideração da pessoa jurídica Tema que tem merecido pequena atenção no âmbito da contratação administrativa é o da desconsideração da pessoa jurídica, que já foi referido de passagem acima, nos comentários ao art. $9^{\circ}$. Trata-se de doutrina desenvolvida no âmbito do direito comparado, destinada a reprimir a utilização fraudulenta de pessoas 
jurídicas. Não se trata de ignorar distinção entre a pessoa da sociedade e a de seus sócios, que era formalmente consagrada pelo art. 20 do Código Civil/1916. Quando a pessoa jurídica for a via para realizacão da fraude, admite-se a possibilidade de superar-se sua existência. Essa questão é delicada, mas está sendo enfrentada em todos os ramos do Direito. Nada impede sua aplicacão no âmbito do Direito Administrativo, desde que adotadas as cautelas cabíveis e adequadas. Não se admite que se pretenda ignorar a barreira da personalidade jurídica sempre que tal se revele inconveniente para a Administracão. A desconsideracão da personalidade societária pressupõe a utilização ilegal, abusiva e contrária às boas práticas da vida empresarial. E a desconsideração deve ser precedida de processo administrativo específico em que sejam assegurados a ampla defesa e o contraditório a todos os interessados." É importante reconhecer que a pessoa jurídica não pode ser manipulada, com o ilícito objetivo de viabilizar o abuso de direito e a prática de fraude, principalmente no que concerne aos procedimentos licitatórios, pois essas são ideias que se revelam frontalmente contrárias ao dever de moralidade e de probidade, que constituem deveres que se impõem à observância da Administração Pública e dos participantes. O licitante de má-fé, por isso mesmo, deve ter a sua conduta sumariamente repelida pela atuação das entidades estatais e de seus órgãos de controle, que não podem tolerar o abuso de direito e a fraude como práticas descaracterizadoras da essência ética do processo licitatório. Vale referir, neste ponto, a edição de importante instrumento normativo, qual seja a Lei $\mathrm{n}^{\circ} 12.846$, publicada em $1^{\circ} \mathrm{de}$ agosto de 2013, ainda em período de vacatio legis, que dispõe sobre a responsabilização administrativa e civil de pessoas jurídicas pela prática de atos contra a administração pública ()", e que disciplina, entre outros dispositivos, a matéria que se vem analisando: Art. $5^{\circ}$ Constituem atos lesivos à administração pública, nacional ou estrangeira, para os fins desta Lei, todos aqueles praticados pelas pessoas jurídicas mencionadas no parágrafo único do art. $1^{\circ}$, que atentem contra 0 patrimônio público nacional ou estrangeiro, contra princípios da administração pública ou contra os compromissos internacionais assumidos pelo Brasil, assim definidos: III - comprovadamente, utilizar-se de interposta pessoa física ou jurídica para ocultar ou dissimular seus reais interesses ou a identidade dos beneficiários dos atos praticados; IV - no tocante a licitações e contratos: e) criar, de modo fraudulento ou irregular, pessoa jurídica para participar de licitação pública ou celebrar contrato administrativo;

Art. 14. A personalidade jurídica poderá ser desconsiderada sempre que utilizada com abuso do direito para facilitar, encobrir ou dissimular a prática dos atos ilícitos previstos nesta Lei ou para provocar confusão patrimonial, sendo estendidos todos os efeitos das sanções aplicadas à pessoa jurídica aos seus administradores e sócios com poderes de administração, observados o contraditório e a ampla defesa." (grifei) É preciso reconhecer, presente esse contexto, que a desconsideração da personalidade jurídica, como anteriormente assinalado, configura prática excepcional, cuja efetivação impõe ao Estado a necessária observância de postulados básicos como a garantia do due process of law, que representa indisponível prerrogativa de índole constitucional assegurada à generalidade das pessoas (...). (grifo nosso)

Verifica-se no julgado supra citado que a Lei Anticorrupção é mencionada como possível meio que possibilitará suprir as lacunas do nosso ordenamento 
jurídico. Entretanto, tendo em vista que o caso foi julgado no período de vacacio legis da Lei, não foi possível que o STF analisasse a Lei de forma concreta.

A personificação no âmbito empresarial consiste na separação da personalidade dos sócios e da pessoa jurídica, assim, com o registro na forma da lei dos seus atos constitutivos, a sociedade adquire autonomia quanto a sua personalidade. Assim afere Gladston Mamede:

(...)Há muito as coletividades são reconhecidas como entes de existência social distinta da existência de seus membros. Por exemplo, todo mundo sabe o que é a Máfia, mas poucos sabem o nome de um de seus membros. (...) No âmbito do Direito, essa percepção evoluiu para a constituição de um artifício jurídico: o reconhecimento das coletividades organizadas como pessoas jurídicas, atribuindo-lhes personalidade distinta da personalidade de seus membros ${ }^{61}$.

Sabe-se que no Brasil a sociedade limitada, a qual possibilita a distinção do patrimônio e limitação da responsabilidade dos sócios, é a forma mais comum escolhida na hora de empreender por conferir maior segurança jurídica e segurança do capital investido, por justamente distinguir o patrimônio pessoal dos sócios daqueles atribuídos a sociedade.

Ocorre que muitas vezes a sociedade passa a exercer suas atividades de forma ilícita, servindo a personalidade jurídica apenas como "véu" para encobrir e dificultar a verificação dos ilícitos cometidos por seus dirigentes. Nestas situações fica claro o abuso de direito, bem como a eminente necessidade de desconsiderar a personalidade da pessoa jurídica, a fim de atingir as pessoas físicas as quais incorrem no delito, no caso, de corrupção.

Vale mencionar que no Direito Brasileiro já há previsão da desconsideração da personalidade jurídica. Em 1990, o Código de Defesa do Consumido foi pioneiro ao estabelecer de forma expressa em seu artigo 28 a possibilidade de aplicação deste instituto o qual já vinha sendo aplicado pela jurisprudência, conforme transcrito abaixo:

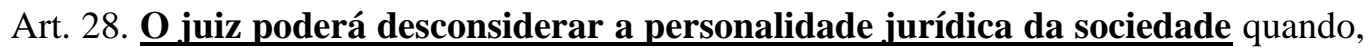
em detrimento do consumidor, houver abuso de direito, excesso de poder, infração da lei, fato ou ato ilícito ou violação dos estatutos ou contrato social. A desconsideração

\footnotetext{
${ }^{61}$ MAMEDE, Gladston. Manual de Direito Empresarial. $9^{\mathrm{a}}$ Ed. São Paulo: Editora Atlas S.A., 2015. p. 38
} 
também será efetivada quando houver falência, estado de insolvência, encerramento ou inatividade da pessoa jurídica provocados por má administração.

$\S 1^{\circ}$ (Vetado).

$\S 2^{\circ}$ As sociedades integrantes dos grupos societários e as sociedades controladas, são subsidiariamente responsáveis pelas obrigações decorrentes deste código.

$\S 3^{\circ}$ As sociedades consorciadas são solidariamente responsáveis pelas obrigações decorrentes deste código.

$\S 4^{\circ}$ As sociedades coligadas só responderão por culpa.

$\S 5^{\circ}$ Também poderá ser desconsiderada a pessoa jurídica sempre que sua personalidade for, de alguma forma, obstáculo ao ressarcimento de prejuízos causados aos consumidores.(grifo nosso)

Visando ainda coibir o abuso de direito, o desvio de finalidade da pessoa jurídica, bem como a facilitação da propagação de ilicitudes através da pessoa jurídica, o Código Civil de 2002 em seu artigo 50 também prevê esta possibilidade da desconsideração, no seguinte sentido:

Art. 50. Em caso de abuso da personalidade jurídica, caracterizado pelo desvio de finalidade, ou pela confusão patrimonial, pode o juiz decidir, a requerimento da parte, ou do Ministério Público quando lhe couber intervir no processo, que os efeitos de certas e determinadas relações de obrigações sejam estendidos aos bens particulares dos administradores ou sócios da pessoa jurídica.

Assim, nesta mesma diretriz de evitar que a personalidade jurídica seja uma barreira para o ressarcimento de prejuízos causados ao erário, bem como forma de encobrir a ilicitude e o abuso de direito, a presente Lei estabelece no artigo 19, inciso III e $\$ 1^{\circ}$ e incisos I e II a dissolução compulsória da pessoa jurídica em decorrência de processo penal-administraivo prévio.

Art. 19. Em razão da prática de atos previstos no art. 5o desta Lei, a União, os Estados, o Distrito Federal e os Municípios, por meio das respectivas Advocacias Públicas ou órgãos de representação judicial, ou equivalentes, e o Ministério Público, poderão ajuizar ação com vistas à aplicação das seguintes sanções às pessoas jurídicas infratoras: (...) III - dissolucão compulsória da pessoa jurídica;

(...) § 10 A dissolução compulsória da pessoa jurídica será determinada quando comprovado:

I - ter sido a personalidade jurídica utilizada de forma habitual para facilitar ou promover a prática de atos ilícitos; ou

II - ter sido constituída para ocultar ou dissimular interesses ilícitos ou a identidade dos beneficiários dos atos praticados.

(...) 
A desconsideração da personalidade jurídica de forma compulsória é uma das mais fortes consequências imposta pela lei para atos extremamente graves, importando o encerramento das atividades da pessoa jurídica. Nas palavras de Egon Moreira e Andreia Cristina Bagatin:

Dentre as mais fortes reações, a Lei Anticorrupção institui a desconsideração total ou despersonificação: a pena capital da dissolução compulsória. $\mathrm{O}$ vício constado é tão grave, que o que se pretende extinguir é a fonte dos atos ilícitos, sua matriz ou causa: isto é, a própria pessoa jurídica. Pessoa jurídica esta que foi institucionalizada - ou cuja existência se presta - ao cometimento de atos de corrupção ${ }^{62}$.

Sublinha-se que a desconsideração compulsória da personalidade jurídica somente poderá ser aplicada se precedida do devido processo penaladministrativo, sendo assegurado as partes os princípios constitucionais estabelecidos no artigo $5^{\circ} \mathrm{LV}^{63}$ quais sejam: o contraditório e ampla defesa.

Verifica-se novamente a função preventiva da Nova Lei na medida em que estimula a institucionalização de mecanismos eficazes que possibilitem coibir a existência de tais práticas no mundo corporativo. Assim, nasce para os empresários a obrigação de estar em conformidade com a Lei Anticorrupção, bem como seus decretos e portarias regulamentadoras, criando programas de compliance nos moldes estabelecidos pela portaria $\mathrm{n}^{\circ} 909$ da Controladoria Geral da União (CGU).

No mundo corporativo atual e para o ordenamento jurídico pátrio, a mera celebração e registro de contrato ou estatuto social já não é mais suficiente, fazendo-se necessário a observância das boas práticas corporativas, as quais incluem os mencionados programas de compliance ${ }^{64}$. Pode-se afirmar ainda que

\footnotetext{
${ }^{62}$ MOREIRA, Egon e BAGATIN, Andreia. Lei Anticorrupção e quatro de seus principais temas Responsabilidade objetiva, desconsideração societária, acordos de leniência e regulamentos administrativos. R. de Dir. Público da Economia-RDPE. Belo Horizonte, ano 12, n.47, p.71, jul./set. 2014

${ }^{63}$ Art. $5^{\circ}$ Todos são iguais perante a lei, sem distinção de qualquer natureza, garantindo-se aos brasileiros e aos estrangeiros residentes no País a inviolabilidade do direito à vida, à liberdade, à igualdade, à segurança e à propriedade, nos termos seguintes: LV - aos litigantes, em processo judicial ou administrativo, e aos acusados em geral são assegurados o contraditório e ampla defesa, com os meios e recursos a ela inerentes.

${ }^{64}$ MOREIRA, Egon e BAGATIN, Andreia. Op. Cit., p. 72
} 
o combate a corrupção integra a função social da empresa passando a ser um critério objetivo com a vigência da Nova Lei.

\subsection{Acordo de Leniência}

Considerando o delito de corrupção, é possível afirmar que a prática do mesmo ocorre de forma discreta, com restrições de informações, gerando grande assimetria de informações entre os envolvidos. Não sendo os atos praticados de forma pública, encontra-se por parte da Administração Pública fiscalizadora, grande dificuldade na apuração de tais delitos, na medida que as informações são de difícil acesso, bem como o agente que tem acesso a estas informações não possui qualquer incentivo para revela-las ${ }^{65}$.

De tal modo, a Lei anticorrupção estabeleceu em seu artigo 16 a possibilidade de celebração de acordo de leniência entre a Administração Pública e as pessoas jurídicas que efetivamente colaborarem com a investigação e com o processo administrativo. In verbis:

Art. 16. A autoridade máxima de cada órgão ou entidade pública poderá celebrar acordo de leniência com as pessoas jurídicas responsáveis pela prática dos atos previstos nesta Lei que colaborem efetivamente com as investigações e o processo administrativo, sendo que dessa colaboração resulte:

I - a identificação dos demais envolvidos na infração, quando couber; e

II - a obtenção célere de informações e documentos que comprovem o ilícito sob apuração.

$\S 10 \mathrm{O}$ acordo de que trata o caput somente poderá ser celebrado se preenchidos, cumulativamente, os seguintes requisitos:

I - a pessoa jurídica seja a primeira a se manifestar sobre seu interesse em cooperar para a apuração do ato ilícito;

II - a pessoa jurídica cesse completamente seu envolvimento na infração investigada a partir da data de propositura do acordo;

III - a pessoa jurídica admita sua participação no ilícito e coopere plena e permanentemente com as investigações e o processo administrativo, comparecendo, sob suas expensas, sempre que solicitada, a todos os atos processuais, até seu encerramento. § 20 A celebração do acordo de leniência isentará a pessoa jurídica das sanções previstas no inciso II do art. 6o e no inciso IV do art. 19 e reduzirá em até 2/3 (dois terços) o valor da multa aplicável.

$\S 30$ O acordo de leniência não exime a pessoa jurídica da obrigação de reparar integralmente o dano causado.

§ 40 O acordo de leniência estipulará as condições necessárias para assegurar a efetividade da colaboração e o resultado útil do processo.

\footnotetext{
${ }^{65}$ Ibidem, p.74
} 
$\S 50$ Os efeitos do acordo de leniência serão estendidos às pessoas jurídicas que integram o mesmo grupo econômico, de fato e de direito, desde que firmem o acordo em conjunto, respeitadas as condições nele estabelecidas.

§ 6o A proposta de acordo de leniência somente se tornará pública após a efetivação do respectivo acordo, salvo no interesse das investigações e do processo administrativo.

$\S 7$ o Não importará em reconhecimento da prática do ato ilícito investigado a proposta de acordo de leniência rejeitada.

§ 80 Em caso de descumprimento do acordo de leniência, a pessoa jurídica ficará impedida de celebrar novo acordo pelo prazo de 3 (três) anos contados do conhecimento pela administração pública do referido descumprimento.

§ 9o A celebração do acordo de leniência interrompe o prazo prescricional dos atos ilícitos previstos nesta Lei.

§ 10. A Controladoria-Geral da União - CGU é o órgão competente para celebrar os acordos de leniência no âmbito do Poder Executivo federal, bem como no caso de atos lesivos praticados contra a administração pública estrangeira.

A leniência é um acordo de resultados, ficando sujeito ao fornecimento de provas e documentos, bem como depoimentos ${ }^{66}$, assim como clara tendência da Administração Pública consensual.

O incentivo oferecido pela Lei Anticorrupção para aqueles que de forma espontânea e facultativa optarem por firmar acordo de leniência é o de possibilitar a redução das seguintes sanções: a dispensa da publicação condenatória (artigo $6^{\circ}$, inciso II); isenção da sanção que proíbe a pessoa jurídica a obter incentivos, empréstimos, doações, subsídios e subvenções do Poder Público (artigo 19, inciso IV) e redução da multa aplicável até dois terços. Nas palavras de Modesto Carvalhosa:

O regime de leniência não visa proteger a pessoa jurídica que o firmou, mas sim estender e aprofundar as investigações a outras pessoas jurídicas e outros agentes públicos implicados, em concurso, nas condutas corruptivas tipificadas na presente Lei $^{67}$.

Existem diversas críticas quanto a este instituto, haja vista que a celebração do acordo não extingue a punibilidade, mas tão somente leva a redução de algumas das sanções aplicáveis, diferente do que ocorre por exemplo na delação premiada ${ }^{68}$ na esfera penal. A extinção da punibilidade de fato não

\footnotetext{
${ }^{66}$ CARVAlHOSA, Modesto. Considerações sobre a Lei Anticorrupção das Pessoas Jurídicas: Lei 12.846/13. $1^{\mathrm{a}}$ ed. São Paulo: Revista dos Tribunais, 2015.p. 378.

${ }^{67}$ Ibidem, p.382.

68 “O instituto da delação premiada consiste em ato do acusado que, admitindo a participação no delito, fornece às autoridades informações eficazes, capazes de contribuir para a resolução do crime.” O conceito
} 
pode ocorrer devido à indisponibilidade do interesse público na reparação do dano no âmbito penal-administrativo. No mais, afere Modesto Carvalhosa:

\begin{abstract}
Essas críticas baseiam-se exatamente no equívoco de entender o acordo de leniência como panaceia universal, pretendendo que seus efeitos se estendam também às esferas criminal, administrativa e civil, em razão dos delitos corruptivos objeto do processo penal-administrativo em curso contra a pessoa jurídica.

O único incentivo do acordo de leniência é o da diminuição das punições (jus puniendi)

(...) não tendo o pacto efeitos além dele, para atingir outras esferas punitivas ou reparatórias previstas no ordenamento jurídico, nas esferas civil, penal e administrativa ${ }^{69}$.
\end{abstract}

Há de se ressaltar que para que seja possível a celebração do acordo, o $§ 1^{\circ}$ do artigo supracitado estabelece requisitos objetivos, devendo a pessoa jurídica (i) ser a primeira a manifestar sua vontade de colaborar com as investigações; (ii) cessar completamente e imediatamente sua participação na infração investigada contada da data de propositura do acordo e (iii) admitir sua participação e cooperar de forma plena nas investigações e respectivo processo administrativo.

Na visão sustentada por Diogo de Figueiredo Moreira Neto e Rafael Veras de Freitas, o terceiro requisito apresenta resquícios de inconstitucionalidade, dado que a "admissão de participação" implica na produção de prova contra si mesmo, indo de encontro com o artigo $5^{\circ}$, inciso LXIII ${ }^{70}$ da Constituição Federal, conforme se extrai da seguinte passagem:

Isso porque "a admissão na participação no ilícito" corresponde, ao fm e ao cabo, em fazer prova contra si, o que viola o disposto no artigo $5^{\circ}$, inciso LXIII da Constituição da República e o artigo 14,3, "g", do Pacto Internacional sobre Direitos Civis e Políticos, do qual o Brasil é signatário ${ }^{71}$.

é da Sexta Turma do Superior Tribunal de Justiça (STJ), aplicado no julgamento do HC 90.962. Disponível em $\quad<\quad$ http://www.stj.jus.br/sites/STJ/default/pt_BR/noticias/noticias/Adela\%C3\%A7\%C3\%A3o-premiada-e-as-garantias-do-colaborador> Acesso em 19/10/2015

${ }^{69}$ CARVALHOSA, Modesto. Considerações sobre a Lei Anticorrupção das Pessoas Jurídicas: Lei 12.846/13. $1^{\text {a }}$ ed. São Paulo: Revista dos Tribunais, 2015.p. 377.

${ }^{70}$ Art. $5^{\circ}$ Todos são iguais perante a lei, sem distinção de qualquer natureza, garantindo-se aos brasileiros e aos estrangeiros residentes no País a inviolabilidade do direito à vida, à liberdade, à igualdade, à segurança e à propriedade, nos termos seguintes: LXIII - o preso será informado de seus direitos, entre os quais o de permanecer calado, sendo-lhe assegurada a assistência da família e de advogado;

71 NETO MOREIRA, Diogo de Figueiredo e FREITAS, Rafael Véras. A juridicidade da Lei Anticorrupção - Reflexões e interpretações prospectivas. Fórum Administrativo-FA. Belo Horizonte, ano 14, n.156, p.9-20, fev. 2014. 
No que se pese a respeitável posição acima mencionada, não nos parece o melhor entendimento, haja vista que o acordo de leniência constitui uma faculdade e não uma obrigação proporcionada pela lei, a fim de possibilitar e aprofundar as investigações dos ilícitos de corrupção. Logo não há o que se falar em violação do artigo $5^{\circ}$ LXIII da Constituição, não havendo qualquer inconstitucionalidade. Novamente a Lei tende a incentivar o controle, a transparência e a verificação de qualquer ato de corrupção, ao possibilitar a denúncia com a verificação de ato ilícito existente e posterior celebração do acordo de leniência entre Administração Pública e pessoa jurídica, a fim de colaborar com as investigações e responsabilizar responsáveis que atentaram contra o bem jurídico tutelado.

\subsection{Sanções}

No que tange a responsabilidade administrativa das pessoas jurídicas na esfera da Lei Anticorrupção, o Processo Administrativo de Responsabilização PAR está estabelecido no Capítulo I do Decreto $\mathrm{n}^{\circ}$ 8420, que regulamenta a Lei Anticorrupção, bem como na Portaria n 910 da Controladoria Geral da União. Este é o procedimento legítimo que precede e possibilita a aplicação das multas previstas no artigo $6^{\circ}$ da Lei Anticorrupção.

Sendo assim, uma vez instaurado o PAR, a aplicação de multa é uma sanção possível, podendo variar de $0,1 \%$ a $20 \%$ do faturamento bruto da empresa relativo ao último exercício da instauração do processo administrativo e da publicação extraordinária da decisão condenatória.

A dosimetria da multa dependerá dentre outros fatores dos atos praticados pela empresa, dos valores dos contratos, bem como de critérios subjetivos elencados nos incisos I a IV do artigo $7^{\circ}$ da lei. Importante ressaltar que foi o Decreto, que especificou de forma mais detalhada os percentuais das multas aplicáveis a cada caso, levando em conta os atos praticados e os valores dos contratos, conforme artigo abaixo transcrito: 
Art. 17. O cálculo da multa se inicia com a soma dos valores correspondentes aos seguintes percentuais do faturamento bruto da pessoa jurídica do último exercício anterior ao da instauração do PAR, excluídos os tributos:

I - um por cento a dois e meio por cento havendo continuidade dos atos lesivos no tempo;

II - um por cento a dois e meio por cento para tolerância ou ciência de pessoas do corpo diretivo ou gerencial da pessoa jurídica;

III - um por cento a quatro por cento no caso de interrupção no fornecimento de serviço público ou na execução de obra contratada;

IV - um por cento para a situação econômica do infrator com base na apresentação de índice de Solvência Geral - SG e de Liquidez Geral - LG superiores a um e de lucro líquido no último exercício anterior ao da ocorrência do ato lesivo;

$\mathrm{V}$ - cinco por cento no caso de reincidência, assim definida a ocorrência de nova infração, idêntica ou não à anterior, tipificada como ato lesivo peloart. $5^{\circ}$ da Lei $n^{\circ}$ 12.846, de 2013, em menos de cinco anos, contados da publicação do julgamento da infração anterior; e

VI - no caso de os contratos mantidos ou pretendidos com o órgão ou entidade lesado, serão considerados, na data da prática do ato lesivo, os seguintes percentuais:

a) um por cento em contratos acima de $\mathrm{R} \$ 1.500 .000,00$ (um milhão e quinhentos mil reais);

b) dois por cento em contratos acima de $\mathrm{R} \$ 10.000 .000,00$ (dez milhões de reais);

c) três por cento em contratos acima de $\mathrm{R} \$ 50.000 .000,00$ (cinquenta milhões de reais);

d) quatro por cento em contratos acima de $\mathrm{R} \$ 250.000 .000,00$ (duzentos e cinquenta milhões de reais); e

e) cinco por cento em contratos acima de $\mathrm{R} \$ 1.000 .000 .000,00$ (um bilhão de reais).

De acordo com o artigo 17 do mencionado decreto, o percentual isolado mais alto é de 5\% o qual aplica-se nos casos de reincidência em um período inferior cinco anos, a contar da publicação da infração anterior.

Um ponto interessante que se pode verificar é o estímulo trazido através do Decreto 8.420 em seu artigo 18, ao estabelecer que as multas poderão ter, entre outros descontos, até $2 \%$ no caso de comunicação espontânea pela pessoa jurídica antes da instauração do processo administrativo acerca da ocorrência do ato lesivo, ou seja, praticar a autodenúncia.

Reafirmando a tendência preventiva da Lei Anticorrupção, o Decreto Regulamentador confere descontos significantes nas multas para as pessoas jurídicas que possuírem mecanismos efetivos de combate a corrupção, denominados de programas de integridade (compliance), desde que atendam aos requisitos objetivos elencados na Portaria da Controladoria Geral da União $n^{\circ}$ 909, conforme mencionado no capítulo 4. 
No que tange a responsabilização judicial da pessoa jurídica, afere o artigo 18 da Lei Anricorrupção:

Art. 18. Na esfera administrativa, a responsabilidade da pessoa jurídica não afasta a possibilidade de sua responsabilização na esfera judicial.

Sendo assim, a lei estabeleceu duas formas de responsabilização: a administrativa, constantes nos artigos $6^{\circ}$ ao 15 e judicial, previstas no artigo 18 a 21 da Lei $^{72}$.

O artigo 19 em seus incisos I a IV elenca as sanções judiciais que podem ser aplicadas aqueles que praticarem os atos lesivos à Administração Pública, podendo ser aplicados de forma única ou cumulativa.

Art. 19. Em razão da prática de atos previstos no art. 5o desta Lei, a União, os Estados, o Distrito Federal e os Municípios, por meio das respectivas Advocacias Públicas ou órgãos de representação judicial, ou equivalentes, e o Ministério Público, poderão ajuizar ação com vistas à aplicação das seguintes sanções às pessoas jurídicas infratoras: I - perdimento dos bens, direitos ou valores que representem vantagem ou proveito direta ou indiretamente obtidos da infração, ressalvado o direito do lesado ou de terceiro de boa-fé;

II - suspensão ou interdição parcial de suas atividades;

III - dissolução compulsória da pessoa jurídica;

IV - proibição de receber incentivos, subsídios, subvenções, doações ou empréstimos de órgãos ou entidades públicas e de instituições financeiras públicas ou controladas pelo poder público, pelo prazo mínimo de 1 (um) e máximo de 5 (cinco) anos.

§ 1o A dissolução compulsória da pessoa jurídica será determinada quando comprovado:

I - ter sido a personalidade jurídica utilizada de forma habitual para facilitar ou promover a prática de atos ilícitos; ou

II - ter sido constituída para ocultar ou dissimular interesses ilícitos ou a identidade dos beneficiários dos atos praticados.

$\S 20$ (VETADO).

§ 30 As sanções poderão ser aplicadas de forma isolada ou cumulativa.

§ 4o O Ministério Público ou a Advocacia Pública ou órgão de representação judicial, ou equivalente, do ente público poderá requerer a indisponibilidade de bens, direitos ou valores necessários à garantia do pagamento da multa ou da reparação integral do dano causado, conforme previsto no art. 7o, ressalvado o direito do terceiro de boa-fé. (grifo nosso)

Neste sentido, a jurisprudência do Tribunal de Justiça do Ceará teve a oportunidade de aplicar a Nova Lei,conforme ementa abaixo descrita:

\footnotetext{
${ }^{72}$ Bittencourt, Sidney. Comentários à Lei Anticorrupção: Lei 12.846/2013, 2 a ed. revista, atualizada e ampliada - São Paulo: Editora Revista dos Tribunais, 2015, p. 164
} 
DIREITO ADMINISTRATIVO E PROCESSUAL CIVIL. AGRAVO DE INSTRUMENTO EM AÇÃO CIVIL PÚBLICA. APURAÇÃO DE IRREGULARIDADES EM LICITAÇÕES NO MUNICÍPIO DE MADALENA/CE. DECRETADA A INDISPONIBILIDADE DE BENS E ATIVOS FINANCEIROS DA AGRAVANTE EM VALOR EQUIVALENTE AO MONTANTE GLOBAL DAS LICITAÇÕES, BEM COMO, A QUEBRA DO SIGILO BANCÁRIO E FISCAL. DESPROPORCIONALIDADE DA MEDIDA. NECESSIDADE DE REDUÇÃO DO BLOQUEIO PARA VALOR RAZOÁVEL EQUIVALENTE AO TOTAL DOS PRODUTOS ENTREGUES AO MUNICÍPIO. COMPATIBILIDADE AO SUPOSTO DANO. RECURSO CONHECIDO E PARCIALMENTE PROVIDO. DECISÃO INTERLOCUTÓRIA REFORMADA. 1. Em princípio, deixarei de me aprofundar na discussão que envolve as irregularidades que teriam resultado nas fraudes dos processos licitatórios, e, que culminaram no ajuizamento da ação civil pública originária, vez que referida matéria está voltada ao próprio mérito daquela ação, pendente ainda de apreciação pelo juízo de primeira instância, sob pena de, em sentido contrário, ocorrer verdadeira supressão de instância. 2. Pois bem, o art. 19, da Lei $\mathbf{n}^{0}$. 12.846/2013 estabelece as sancões judiciais que serão aplicadas às pessoas jurídicas infratoras, dentre as quais 0 perdimento dos bens, direitos ou valores que representem vantagem ou proveito direta ou indiretamente obtidos da infracão. Como meio de assegurar o ressarcimento do dano causado ao erário, é plenamente cabível a determinação, como fez o juízo a quo, da indisponibilidade dos bens, direitos ou valores da pessoa jurídica acionada, sendo esta medida disciplinada no parágrafo $\S$ $4^{\circ}$, do art. 19, da citada lei. Registre-se que a medida cautelar de indisponibilidade de bens pode ser decretada independentemente da comprovação de que o réu esteja delapidando seu patrimônio ou na iminência de fazê-lo, tendo em vista que o periculum in mora, nesta hipótese é presumido, prevalecendo, portanto, a garantia de ressarcimento do dano. 3. A questão então é saber qual o parâmetro razoável para fixar o limite da indisponibilidade de bens e valores da empresa recorrente. Se o magistrado entendeu que não seria prudente fixar o limite da constrição no montante total do dano causado ao erário, com base no mesmo raciocínio, não seria prudente limitá-la ao valor global das licitações, pois na medida em que foi possível a individualização da participação de cada réu, também poderia ser estabelecido um denominador mais próximo do prejuízo concreto que cada uma das pessoas jurídicas promovidas produziu em tese. 4. Como demonstração deste raciocínio, no caso em espécie, o valor global do Pregão $n^{\circ}$. 2014.05.02.001, foi de R\$ 1.144.942,10 (um milhão, cento e quarenta e quatro mil, novecentos e quarenta e dois reais e dez centavos), contudo o valor referente aos lotes arrematados pela agravante se resume a $\mathrm{R} \$ 518.233,61$ (quinhentos e dezoito mil, duzentos e trinta e três reais e sessenta e um centavos). Por sua vez, a ação ministerial se deu no decorrer da execução do respectivo contrato administrativo, o qual apesar de gerar obrigações recíprocas entre as partes, também não pode ser apontado como parâmetro para fixar o valor da indisponibilidade dos bens da agravante, diante da permissão da administração pública rescindi-lo unilateralmente, por motivo de interesse público, a qualquer tempo, ou seja, antes do seu cumprimento integral. 5. Portanto, para satisfazer o interesse coletivo sem sacrificar a própria continuidade das atividades da recorrente, principalmente num momento em que a discussão se encontra em fase preliminar, sem que a sua responsabilidade tenha sido definitivamente estabelecida, o razoável é fixar o teto da indisponibilidade de seus bens e ativos financeiros no valor das mercadorias efetivamente entregues ao Município de Madalena, que no caso corresponde a $\mathrm{R} \$ 132.946,26$ (cento e trinta e dois mil, novecentos e quarenta e seis reais e vinte e seis centavos), pois este ato (entrega de 
produtos) consolida um direito/obrigação de contraprestação pecuniária e, consequentemente, resulta em inevitável prejuízo ao erário. (...) (grifo nosso) ${ }^{73}$

Deste modo, conforme vem se demonstrando no decorrer do presente trabalho, bem como neste capítulo, é explícito o dever de colaboração das pessoas jurídicas nas investigações de atos ilícitos tipificados na Nova Lei. O artigo $7^{\circ}$, incisos VII e VIII deixam de forma clara e expressa a possibilidade de redução das sanções caso haja de fato uma cooperação na apuração dos atos de corrupção, bem como procedimentos internos de integridade, de maneira a incentivar a prevenção e transparência no meio corporativo.

\subsection{Prescrição}

Na esfera jurídica, podemos definir prescrição como o modo pelo qual o direito se extingue, tendo em vista a inércia do seu titular, por determinado lapso de tempo ${ }^{74}$.

Neste sentido, a presente Lei estabelece que a pretensão punitiva das pessoas jurídicas por atos lesivos à Administração Pública prescreve em cinco anos contados da data da ciência da infração ou, no caso de infração permanente ou continuada, do dia em que tiver cessado, nos termos do caput do artigo 25.

Art. 25. Prescrevem em 5 (cinco) anos as infrações previstas nesta Lei, contados da data da ciência da infração ou, no caso de infração permanente ou continuada, do dia em que tiver cessado.

Parágrafo único. Na esfera administrativa ou judicial, a prescrição será interrompida com a instauração de processo que tenha por objeto a apuração da infração.

No entanto, vale ressaltar que a pretensão de ressarcimento ao erário é imprescritível nos termos do artigo 37 , da Constituição Federal ${ }^{75}$. In verbis:

\footnotetext{
${ }^{73}$ TJ-CE , processo n ${ }^{\circ}$ 0620013-07.2015.8.06.0000, Rel. MARIA VILAUBA FAUSTO LOPES, $6^{\mathrm{a}}$ Câmara Cível, Ceará, 24 jun. 2015

${ }^{74}$ Ibidem, p. 180

${ }^{75}$ OLIVEIRA, Rafael Carvalho Rezende e NEVES, Daniel Amorim Assumpção. O sistema brasileiro de combate à corrupção e a Lei $n^{\circ}$ 12.846/2013 (Lei Anticorrupção). Revista brasileira de Dirreito Público - RBDP, Belo Horizonte, ano 12, n. 44, p. 19, jan./mar. 2014
} 
Art. 37. A administração pública direta e indireta de qualquer dos Poderes da União, dos Estados, do Distrito Federal e dos Municípios obedecerá aos princípios de legalidade, impessoalidade, moralidade, publicidade e eficiência e, também, ao seguinte:

$\S \mathbf{5}^{\circ}$ A lei estabelecerá os prazos de prescrição para ilícitos praticados por qualquer agente, servidor ou não, que causem prejuízos ao erário, ressalvadas as respectivas ações de ressarcimento.

Apesar de controverso o tema quanto a imprescritibilidade das ações de ressarcimento ao erário, a maior parte da doutrina, incluindo o TCU e STF, sustentam tal tese, conforme jurisprudência abaixo:

SUMÁRIO: INCIDENTE DE UNIFORMIZAÇÃO DE JURISPRUDÊNCIA. INTERPRETAÇÃO DA PARTE FINAL DO $\S 5^{\circ}$ DO ART. 37 DA CONSTITUIÇÃO FEDERAL. IMPRESCRITIBILIDADE DAS AÇÕES DE RESSARCIMENTO AO ERÁRIO. CONSONÂNCIA COM POSICIONAMENTO RECENTE DO SUPREMO TRIBUNAL FEDERAL. REMESSA DE CÓPIA DO ACÓRDÃO À COMISSÃO DE JURISPRUDÊNCIA DO TCU.

(...)

2. Avalia-se nesta oportunidade a melhor exegese para o $\S 5^{\circ}$ do artigo 37 da Constituição Federal no que tange às ações de ressarcimento decorrentes de prejuízo ao erário. A redação da citada norma constitucional, conforme demonstram os pareceres emitidos nos autos, proporciona duas interpretações divergentes: a que conclui pela imprescritibilidade da pretensão de ressarcimento ao erário e a que conclui pela prescritibilidade da pretensão de ressarcimento, da mesma forma como ocorre com a pretensão punitiva.

3. Anteriormente, me perfilei à segunda corrente com espeque na proeminência do Princípio da Segurança Jurídica no ordenamento pátrio. Não obstante, em 4.9.2008, o Supremo Tribunal Federal, cuja competência precípua é a guarda da Constituição, ao apreciar o Mandado de Segurança n $\mathrm{n}^{\circ}$ 26.210-9/DF, deu à parte final do $\S 5^{\circ}$ do art. 37 da Constituição Federal a interpretação de que as ações de ressarcimento são imprescritíveis. O eminente Relator, Ministro Ricardo Lewandowski, destacou:

"No que tange à alegada ocorrência de prescrição, incide, na espécie, o disposto no art. $37, \S 5^{\circ}$ da Constituição de 1988 , segundo o qual:

$\S 5^{\circ}$ - A lei estabelecerá os prazos de prescrição para ilícitos praticados por qualquer agente, servidor ou não, que causem prejuízos ao erário, ressalvadas as respectivas ações de ressarcimento.

Considerando ser a Tomada de Contas Especial um processo administrativo que visa a identificar responsáveis por danos causados ao erário, e determinar o ressarcimento do prejuízo apurado, entendo aplicável ao caso sob exame a parte final do referido dispositivo constitucional.

Nesse sentido é a lição do Professor José Afonso da Silva:

(...) 'A lei estabelecerá os prazos de prescrição para ilícitos praticados por qualquer agente, servidor ou não, que causem prejuízos ao erário, ressalvadas as respectivas ações de ressarcimento'. Vê-se, porém, que há uma ressalva ao princípio. Nem tudo prescreverá. Apenas a apuração e punição do ilícito, não, porém, o direito da Administração ao ressarcimento, à indenização, do prejuízo causado ao erário. É uma ressalva constitucional e, pois, inafastável, mas, por certo, destoante dos princípios jurídicos, que não socorrem quem fica inerte (dormientibus non sucurrit ius)".

4. A temática aqui analisada trata exclusivamente de interpretação de dispositivo constitucional. Considerando que o STF, intérprete maior e guarda da Constituicão, já se manifestou no sentido de que a parte final do $\$ 5^{\circ}$ do art. 37 da 
Carta Política determina a imprescritibilidade das ações de ressarcimento ao erário, não me parece razoável adotar posição diversa na esfera administrativa. (Grifo nosso).

Conclui-se que a regra estabelecida no artigo $37 \S 5^{\circ}$ da Constituição é uma exceção a regra geral. Prevalece a prescrição definida pelo legislador infraconstitucional, salvo nas hipóteses de imprescritibilidade previstas na Constituição Federal. 


\section{A importância da nova lei no contexto atual}

Como já antes mencionado, a Lei 12.846/2013 está de acordo com diversos diplomas normativos internacionais como tratados e convenções que dispõem sobre o tema Anticorrupção. Dentre eles estão a Convenção Interamericana contra a Corrupção, internalizada através do Decreto Presidencial no 4.410/2002, a Convenção das Nações Unidas contra a Corrupção, a Convenção sobre Combate da Corrupção de Funcionários Públicos Estrangeiros da OCDE, dentre outros ${ }^{76}$.

O presente trabalho não tem o condão de discorrer sobre os diplomas e sistemas internacionais de combate a corrupção, entretanto, vale mencionar a legislação Norte Americana FCPA ("Foreign Corrupt Practices Act") e a UK Bribery Act, uma vez que estas são as mais importantes no cenário mundial.

\subsection{FCPA}

O FCPA foi promulgado em 1977 com o objetivo de tornar ilegal o pagamento por certas classes de pessoas e entidades para funcionários públicos no exterior com o intuito de assistir ou manter negócios ${ }^{77}$. Em 1998, algumas emendas foram realizadas, as quais possibilitaram a aplicação da legislação para empresas estrangeiras e pessoas que causem, direta ou indiretamente mediante agentes, um ato que favoreça o pagamento que tenham conexão com o território dos Estados Unidos ${ }^{78}$. É portanto, aplicável a empresas com sede nos EUA, bem como a empresas estrangeiras que tenham ações cotadas das Bolsas de Valores Norte-Americanas ou que lá praticarem atos de corrupção.

Pode-se dizer que esta legislação está dividida em duas seções, sendo uma parte voltada para o regime Anticorrupção, incluindo previsões antissuborno, e uma seção contendo previsões contábeis a fim de proporcionar controles rígidos

\footnotetext{
${ }^{76}$ CUÉLLAR, Leila e PINHO, Clóvis. Reflexões sobre a lei 12.846/2013 (Lei Anticorrupção). Revista de Direito Público da Economia -RDPE. Belo Horizonte, ano 12. n. 46, p. 138, abr./jun.2014

${ }^{77}$ Disponível em < http://www.justice.gov/criminal-fraud/foreign-corrupt-practices-act > Acesso em $23 / 10 / 2015$

${ }^{78}$ Ibidem.
} 
e transparentes, tonando-se quase impossível encobrir qualquer ato de corrupção $^{79}$.

Em caso recente julgado pela Comissão de Valores Mobiliários americana (Securities and Exchange Commision - SEC) condenou um conglomerado baseado em Tóquio (Hitachi Ltd.) pela violação do FCPA ao verificarem pagamentos para um partido político na África do Sul com conexões diretas a contratos cujo escopo bilionário seria a construção de usinas, tendo a empresa concordou em firmar acordo mediante pagamento de dezenove milhões de dólares ${ }^{80}$.

Outro caso interessante julgado pela SEC foi relacionado a empresa médica Biomet Inc. baseada em Varsóvia, pelo descumprimento da legislação americana do FCPA, na medida em que suas subsidiárias e agentes pagaram subornaram, por mais de uma década, médicos do serviço público da Argentina, Brasil e China para continuarem com seus negócios, tendo a empresa concordado em firmar acordo mediante o pagamento de mais de vinte e dois milhões de dólares ${ }^{81}$.

\subsection{UK Bribery Act}

Mais recente que a legislação americana, passou a vigorar em $1^{\circ}$ de julho de 2011, com o objetivo de combater a corrupção de maneira mais ampla, de modo a balancear a responsabilidade corporativa e o interesse público ${ }^{82}$. Neste sentido, segue o trecho extraído do manual do Governo Britânico sobre o UK Bribery Act:

O suborno mina a democracia e o Estado de Direito e coloca sérias ameaças ao constante progresso econômico nas economias emergentes e em desenvolvimento e para o bom funcionamento dos mercados livres de maneira geral. O Bribery Act 2010 destina-se a responder estas ameaças e a vasta gama de maneiras nas quais o suborno

\footnotetext{
${ }^{79}$ Disponível em < http://gestaotransparente.org/fcpa-foreign-corrupt-practies-act/> Acesso em 23/10/2015

${ }^{80}$ Disponível em < http://www.sec.gov/spotlight/fcpa/fcpa-cases.shtml > Acesso em 23/10/2015

${ }^{81}$ Ibidem.

${ }^{82}$ GIOVANNI, Wagner. Compliance A excelência na prática, $1^{\mathrm{a}}$ ed. -São Paulo, 2014, p. 27
} 
pode ser cometido. Isso se permite através de sanções robustas, reforços dos poderes de condenação para os tribunais (aumentando a pena máxima para o suborno cometido de 7 a 10 anos de prisão) e amplos poderes jurisdicionais ${ }^{83}$.

\subsection{Lei Anticorrupção no âmbito nacional}

Como se verificou a Nova Lei é uma adequação da legislação brasileira a uma tendência internacional e necessidade nacional. No capítulo 2 e 3 do presente trabalho pode-se verificar como a corrupção afeta diretamente o Estado democrático de Direito e provoca consequências devastadoras.

Não obstante, hoje no Brasil, está em foco um dos maiores escândalos de corrupção da história: a corrupção sistêmica na Petrobras cuja operação de investigação denominou-se "Operação Lava Jato". A Petrobras divulgou com atraso no início do ano seu balanço, no qual afere um prejuízo estimado em 6,1 bilhões de reais devido a corrupção ${ }^{84}$.

A operação teve início no início de 2014 com o principal objetivo de apurar desvios e lavagem de dinheiro público através da Petrobras, empreiteiras e partidos políticos. É importante mencionar que, não obstante as ações penais, o Ministério Público Federal ajuizou ação civil pública contra as maiores empreiteiras dos Brasil que estão envolvidas nas investigações, visando a cobrança de $\mathrm{R} \$ 4,5$ bilhões em indenizações, incluindo $\mathrm{R} \$ 319$ milhões de ressarcimento ao erário, indenização por danos morais coletivos de $\mathrm{R} \$ 3,19$ bilhões e multa civil de $\mathrm{R} \$ 959$ milhões de reais ${ }^{85}$. Da ação civil pública por ato de improbidade administrativa pode-se extrair o seguinte trecho:

No âmbito criminal, os réus foram denunciados pela prática dos delitos de organização criminosa (art. $1^{\circ}, \S 1^{\circ}$, da Lei 12.850/2013), corrupção ativa e passiva (arts. 333 e 317 do Código Penal), lavagem de dinheiro (art. $1^{\circ}$ da Lei 9.613/98) e crimes contra o sistema financeiro nacional (arts. 16, 21, parágrafo único, e 22, caput e parágrafo único,

\footnotetext{
83 Ministry of Justice. The Bribery Act 2010 Guidance. Reino Unido, p. 9. 2010. Disponível em <http://www.justice.gov.uk/downloads/legislation/bribery-act-2010-guidance.pdf> Acesso em 23/10/2015

84 Disponível em: < http://arte.folha.uol.com.br/poder/operacao-lava-jato/\#capitulo6> Acesso em 23/10/2015

${ }^{85}$ Secretaria de Comunicação Social. Procuradoria-Geral da República. Lava-Jato: Ações de improbidade do MPF cobram $R \$ 4,47$ bilhões por desvios de recursos da Petrobras . Disponível em: < http://www.prpr.mpf.mp.br/news/lava-jato-acoes-de-improbidade-do-mpf-cobram-r-4-47-bilhoes-pordesvios-de-recursos-da-petrobras> Acesso em 26/10/2015
} 
da Lei 7.492/1986). Tais condutas têm inegáveis reflexos no âmbito cível, em especial no campo de aplicação das Leis 7.347/85, 8.429/92 e $\underline{\mathbf{1 2 . 8 4 6 / 1 3}}$, entre outros diplomas legais ${ }^{86}$. (grifo nosso)

Pode-se verificar portanto que a Operação Lava Jato já pode de certa forma aplicar a Lei Anticorrupção como forma de punir atos corruptos pelas pessoas jurídicas envolvidas na formação de cartel e pagamento de propina, dede que verificados os critérios de aplicabilidade dado que sua vigência ocorreu no dia 29 de janeiro de 2014.

Os efeitos econômicos da corrupção são devastadores e, no caso específico da Petrobras, podem gerar um impacto de $\mathrm{R} \$ 87$ bilhões no valor de produção da economia brasileira no ano de 2015, bem como a perda de mais de 1 milhão de postos de trabalho, segundo estudo elaborado pelo Grupo de Economia \& Soluções Ambientais da Fundação Getúlio Vargas (FGV) ${ }^{87}$.

É neste contexto que a Lei Anticorrupção surge, sendo claramente imprescindível para a batalha contra a corrupção sistêmica no Brasil, tanto no âmbito público quanto no privado. Em um momento de crise econômica, política e social, é necessário que hajam mecanismos jurídicos eficientes que possibilitem a responsabilização e o combate a corrupção.

\footnotetext{
${ }^{86}$ MPF, Ação Civil Pública por Ato de Improbidade Administrativa no 5006628-92.2015.4.04.7000, Deltan Martinazzo Dallagnol, Curitiba 20 fev. 2015

${ }^{87}$ Lava Jato pode ter impacto de R\$87 bilhões na economia, diz estudo. G1, São Paulo, 2 abr. 2015. Disponível em < http://g1.globo.com/economia/negocios/noticia/2015/04/lava-jato-pode-ter-impacto-der-87-bilhoes-na-economia-diz-estudo.html> Acesso em26/10/2015
} 


\section{Conclusão}

Conforme mencionado durante o presente trabalho, a Lei Anticorrupção tem caráter preventivo, na medida em que estimula a criação de programas de conformidade que possibilitem maior transparência das pessoas jurídicas, de forma a evitar a corrupção.

Não basta que a existência de tais programas de conformidade estejam restritos apenas ao papel, devendo o mesmo ser notavelmente conhecido por todos aqueles que integram a pessoa jurídica, criando uma verdadeira cultura de compliance dentro da empresa. O programa de conformidade deve promover de forma efetiva e transparente o combate à corrupção, devendo ainda estar de acordo com os critérios objetivos estabelecidos pelo Decreto n 8.420 de 2015. Esta nova obrigação, assim como as consequências de sua não observância, são de suma importância para os empresários que atuem no âmbito nacional.

Ademais, a Lei encontra sua constitucionalidade no princípio da moralidade administrativa constante no artigo $5^{\circ}$, inciso LXXIII e artigo $37^{\circ}$, parágrafo $9^{\circ}$ da Constituição Federal, reafirmando a manutenção do Estado Democrático de Direito, na medida em que promove o combate à corrupção.

É importante ressaltar ainda que, conforme verificado ao decorrer do presente trabalho, a Nova Lei é fruto de um conjunto de fatores: a forte tendência mundial de implementação de mecanismos ao combate à corrupção, os tratados internacionais ratificados pelo Brasil e o contexto político-econômico nacional.

Conclui-se que apesar de juridicamente ser este um passo importante ao combate à corrupção, apenas os atos isolados da promulgação da lei, decretos e portarias não restam suficientes para eliminar a corrupção que é tão prejudicial à população brasileira e que retira do erário cifras astronômicas que poderiam ser investidas em serviços públicos básicos de qualidade para a população.

Sendo a corrupção fator histórico, diretamente ligado a cultura dos brasileiros, é necessário o reforço na educação para que a longo prazo a corrupção, bem como tantos outros problemas, sejam mitigados. Não excluindo ainda, a necessidade da correta aplicação da Lei pela Administração Pública, a 
fim de efetivamente responsabilizar os envolvidos nos atos tipificados na Lei, mediante o devido processo legal, assegurados os princípios constitucionais do contraditório e ampla defesa para as pessoas jurídicas envolvidas. 


\section{Referência Bibliográfica}

APUD SILVEIRA, Daniel Barile da, op. cit. Disponível em: <http://portalrevistas.ucb.br/index.php/rvmd/article/viewfile/2598/1589.html> Acesso em 19/08/2015

BARBA, Mariana. Corrupção no Brasil tem origem no período colonial. BBC Brasil, São Paulo, 4 nov 2012, disponível em < http://www.bbc.com/portuguese/noticias/2012/11/121026_corrupcao_origens_m db.shtml> Acesso em 20/08/2015

BITTENCOURT, Sidney. Comentários à Lei Anticorrupção: Lei 12.846/2013, 2a ed. revista, atualizada e ampliada - São Paulo: Editora Revista dos Tribunais, 2015

BOTTINI, Pierpaolo. A controversa da responsabilidade objetiva na Lei Anticorrupção. Valor Econômico, 9 dez 2014.

CARVAlHOSA, Modesto. Considerações Sobre A Lei Anticorrupção Das Pessoas Jurídicas - Lei 12.846/2013

CARVAlHOSA, Modesto. A Nova Lei da Empresa Limpa. Estadão, São Paulo, 30 jan 2014. Disponível em < http://opiniao.estadao.com.br/noticias/geral,anova-lei-da-empresa-limpa-imp-,1124715> Acesso em 26 maio 2015.

Controladoria Geral da União. Participação do Brasil em Convenções Internacionais sobre o Combate à Corrupção. Disponível em: <https://bvc.cgu.gov.br/bitstream/123456789/2736/1/participacao_do_Brasil_em. pdf> Acesso em 26 maio 2015. 
Controladoria Geral da União. Participação do Brasil em Convenções Internacionais sobre o Combate à Corrupção. Disponível em: $<$ https://bvc.cgu.gov.br/bitstream/123456789/2736/1/participacao_do_Brasil_em. pdf> Acesso em 26 maio 2015.

CUÉLlAR, Leila e PINHO, Clóvis. Reflexões sobre a lei 12.846/2013 (Lei Anticorrupção). Revista de Direito Público da Economia -RDPE. Belo Horizonte, ano 12. n. 46, p. 144, abr./jun.2014

DA COSTA, Hekelson Bitencourt Viana. Lavagem de Dinheiro - Lei $\mathrm{n}^{\circ}$ 9.613/98. Revista de Informação Legislativa. Brasília a. 38 n. 150 abr./jun. 2001. Disponível em <http://www2.senado.leg.br/bdsf/bitstream/handle/id/682/r15008.pdf?sequence $=4>$ Acesso em 02/09/2015

Decreto $\mathrm{n}^{\mathrm{o}} 8420$ de 18 de março de 2015. Disponível em: $<$ http://www.planalto.gov.br/ccivil_03/_Ato20152018/2015/Decreto/D8420.htm> Acesso em 15/09/2015

Disponível em: <http://www.contracorrupcao.org/2013/08/como-era-corrupcaona-epoca-do.html > Acesso em 19/08/2015

Disponível em < http://www.transparency.org/cpi2014> Acesso em 02/09/2015

Disponível em < http://gestaotransparente.org/fcpa-foreign-corrupt-practies-act/> Acesso em 23/10/2015

Disponível em <http://www.oab.org.br/noticia/27880/oab-se-manifesta-contra-acorrupcao-e-pelo-direito-de-defesa>

Disponível em < http://www.sec.gov/spotlight/fcpa/fcpa-cases.shtml> Acesso em $23 / 10 / 2015$ 
DOS SANTOS, Renato Almeida; GUEVARA, Arnaldo José de Hoyos; AMORIM, Cristina Sanches e FERRAZ-NETO, Ben-Hur. Compliance e liderança: a suscetibilidade dos líderes ao risco de corrupção nas organizações. Einstein (São Paulo) vol.10 no.1 São Paulo jan./mar. 2012

Exposição de Motivos do PL 6.826/2010. Disponível em: <http://www.camara.gov.br/proposicoesWeb/prop_mostrarintegra;jsessionid=A9 60D383A530729356645A9A86AD66AD.node1 codteor $=1084183 \&$ filename $=\mathrm{A}$ vulso+-PL+6826/2010> Acesso em 26 maio 2015.

FILGUEIRAS, Fernando. A tolerância à corrupção no Brasil: uma antinomia entre normas morais e prática social. OPINIÃO PÚBLICA, Campinas, vol. 15, n ${ }^{\circ}$ 2, Novembro, 2009, p.391. Disponível em < http://www.scielo.br/pdf/op/v15n2/05.pdf> Acesso em 02/09/2015.

GARCIA, Emerson. A corrupção. Uma Visão Juridico-Sociológica, 2008, p. 11, disponível em: http://www.tjrj.jus.br/institucional/dir_gerais/dgcon/pdf/artigos/direi_const/a_cor rupcao_uma_visao.pdf> Acesso em 26 maio 2015.

GIOVANNI, Wagner. Compliance A excelência na prática, $1^{\text {a }}$ ed. -São Paulo, 2014

GODINHO, Thiago. Contribuições Do Direito Internacional Ao Combate à Corrupção. In: Rev. Fac. Direito UFMG, Belo Horizonte, jan./jun. 2011

HOUAISS, Antônio. Dicionário Houaiss

Lava Jato pode ter impacto de $\mathrm{R} \$ 87$ bilhões na economia, diz estudo. G1, São Paulo, 2 abr. 2015. Disponível em 
http://g1.globo.com/economia/negocios/noticia/2015/04/lava-jato-pode-terimpacto-de-r-87-bilhoes-na-economia-diz-estudo.html> Acesso em26/10/2015

MAMEDE, Gladston. Manual de Direito Empresarial. $9^{\text {a }}$ Ed. São Paulo: Editora Atlas S.A., 2015. p. 38

Ministry of Justice. The Bribery Act 2010 Guidance. Reino Unido, p. 9. 2010. Disponível em <http://www.justice.gov.uk/downloads/legislation/bribery-act2010-guidance.pdf> Acesso em 23/10/2015

MOREIRA, Egon e BAGATIN, Andreia. Lei Anticorrupção e quatro de seus principais temas - Responsabilidade objetiva, desconsideração societária, acordos de leniência e regulamentos administrativos. R. de Dir. Público da EconomiaRDPE. Belo Horizonte, ano 12, n. 47, p.72, jul./set. 2014

MPF, Ação Civil Pública por Ato de Improbidade Administrativa $n^{\circ}$ 500662892.2015.4.04.7000, Deltan Martinazzo Dallagnol, Curitiba 20 fev. 2015 NETO, Affonso Ghizzo. Corrupção, Estado Democrático de Direito e Educação, 2008, p. 20.2 Disponível em: $<$ http://www.unisc.br/portal/upload/com_arquivo/dissertacao__corrupcao_estad o_democratico_de_direito_e_educacao.pdf> Acesso em19/08/2015

NETO, Diogo de Figueiredo Moreira e FREITAS, Rafael Véras. A juridicidade da Lei Anticorrupção - Reflexões e interpretações prospectivas. Disponível em: http://www.mpsp.mp.br/portal/page/portal/cao_cidadania/LeiAnticorrupcao/LeiA nticorrupcao Doutrina/A\%20juridicidade\%20da\%20Lei\%20Anticorrup\%C3\%A 7\%C3\%A30\%20-

\%20Reflex\%C3\%B5es\%20e\%20interpreta\%C3\%A7\%C3\%B5es\%20prospectiva s\%20-\%20RJ\%20-\%202014.pdf> Acesso em 26 maio 2015. 
OLIVEIRA, Rafael Carvalho Rezende e NEVES, Daniel Amorim Assumpção. O sistema brasileiro de combate à corrupção e a Lei $\mathrm{n}^{\circ}$ 12.846/2013 (Lei Anticorrupção). Revista brasileira de Dirreito Público - RBDP, Belo Horizonte, ano 12, n. 44, p. 19, jan./mar. 2014

ORGANIZAÇÃO PARA A COOPERAÇÃO E DESENVOLVIMENTO ECONÔ- MICO - OCDE. Relatório sobre a aplicação da Convenção sobre o Combate ao Suborno de Funcionários Públicos Estrangeiros em Transações Comerciais Internacionais e a Recomendação Revisada de 1997 sobre o Combate ao Suborno em Transações Comerciais Internacionais da OCDE de dezembro de 2007.

Portaria CGU n ${ }^{\circ} 909$ de 07 de abril de 2015; disponível em: $<$ http://www.cgu.gov.br/sobre/legislacao/arquivos/portarias/portaria_cgu_909_20 15.pdf> Acesso em 16/09/2015

POPE, J. The Elements of a National Integrity System. Transparency International source book 2000

QUINTO, Cristina Alcântara. 10 Anos do Código Civil de 2002. Disponível em <http://www.emerj.tjrj.jus.br/serieaperfeicoamentodemagistrados/paginas/series/ 13/volumeI/10anosdocodigocivil_97.pdf> Acesso em 14/10/2015

ROCHA, Lucas. As Raízes da Corrupção No Brasil - Estudos de Casos e Lições Para o Futuro.

ROSSI, Mariana. Ranking Internacional de corrupção mostra um Brasil estagnado. El País, São Paulo, 3 dez 2005, disponível em < http://brasil.elpais.com> Acesso em 26 maio 2015. 
Secretaria de Comunicação Social. Procuradoria-Geral da República. Lava-Jato: Ações de improbidade do MPF cobram $\mathrm{R} \$ 4,47$ bilhões por desvios de recursos da Petrobras . Disponível em: < http://www.prpr.mpf.mp.br/news/lava-jatoacoes-de-improbidade-do-mpf-cobram-r-4-47-bilhoes-por-desvios-de-recursosda-petrobras> Acesso em 26/10/2015 